NBER WORKING PAPER SERIES

TWO CENTURIES OF FINANCE AND GROWTH IN THE UNITED STATES, 1790-1980

\author{
Howard Bodenhorn \\ Working Paper 22652 \\ http://www.nber.org/papers/w22652 \\ NATIONAL BUREAU OF ECONOMIC RESEARCH \\ 1050 Massachusetts Avenue \\ Cambridge, MA 02138 \\ September 2016
}

The views expressed herein are those of the author and do not necessarily reflect the views of the National Bureau of Economic Research.

NBER working papers are circulated for discussion and comment purposes. They have not been peer-reviewed or been subject to the review by the NBER Board of Directors that accompanies official NBER publications.

(C) 2016 by Howard Bodenhorn. All rights reserved. Short sections of text, not to exceed two paragraphs, may be quoted without explicit permission provided that full credit, including () notice, is given to the source. 
Two Centuries of Finance and Growth in the United States, 1790-1980

Howard Bodenhorn

NBER Working Paper No. 22652

September 2016

JEL No. G2,N2

\begin{abstract}
$\underline{\text { ABSTRACT }}$
Do efficient financial markets and institutions promote economic growth? Have they done so in the past? In this essay, to be included in the Handbook of Finance and Development (edited by Thorsten Beck and Ross Levine), I survey a large and diverse historical literature that explores the connection between finance and growth in US history. The US financial system was important in mobilizing savings, allocating capital, exerting corporate control, and mitigating borrower opportunism. US finance was characterized by a wide variety of intermediaries commercial banks, savings banks, building and loan associations, mortgage companies, investment banks and securities markets - that emerged to fill specific financial niches, compete with and complement the activities of existing intermediaries. The weight of the evidence is consistent with the interpretation that finance facilitated and encouraged growth. Despite the breadth and diversity of approaches, there remain many potentially fruitful lines of further inquiry.
\end{abstract}

Howard Bodenhorn

John E. Walker Department of Economics

College of Business and Behavioral Science

201-B Sirrine Hall

Clemson University

Clemson, SC 29634

and NBER

bodenhorn@gmail.com 


\section{Two centuries of finance and growth in the United States, 1790-1980}

\section{Introduction}

Throughout the twentieth century economic historians, especially the so-called "new" economic historians or cliometricians, have debated the nature of industrial, agricultural, transportation, and even market revolutions (Mokyr 1999; Olmstead and Rhode 2008; Taylor 1951; Sellers 1991). In many of these discussions finance was pushed to the sideline. If finance was considered at all, it was thought to have secondorder and indirect influence on long-run development. Nevertheless, a small group of early cliometricians labored on believing that finance was more important than the existing literature presumed and had yet to receive its due (Cameron et al 1967). Financial historians' early attempts to impress upon their skeptical peers the importance of finance pointed to the experiences of the successful developers: the Low Countries in the seventeenth century, England in the eighteenth, the United States in the mid-nineteenth, Germany in the late nineteenth and, perhaps, Japan in the early twentieth. In each case, the emergence of an innovative financial sector predated the emergence of an economic powerhouse (Sylla 2002). A proliferation of the number and variety of financial institutions was a nearly universal characteristic of the early stages of modern economic development in the successful developers. It is an empirical observation, write Cameron and Patrick (1967, p.1) that "admits no exceptions."

The causal nexus of this relationship is not clear, however. Does it run from finance to growth and modernization or, does the advance of industrialization leave a number of financial intermediaries in its wake? It is no easy task to sort this out because skeptics claim, and not unreasonably, that finance tends to develop as the demand for it develops. They sometimes offer a sort of reverse Says Law: demand creates its own supply. Those who believe in the centrality of finance, however, start from the premise that capital markets are integral to capitalism and, therefore, to capitalist development so that finance is more a leading than lagging sector. A more 
subtle view accepts the possibility of feedback loops and bi-directional causality. In their historical study of small and medium-size enterprises (SMEs), Cull et al (2006, p.3020) show that small businesses obtained financial assistance from an "impressive array" of local financial intermediaries, which appear to have emerged endogenously to meet the needs of SMEs. But to say that finance emerged endogenously is not to say that it followed rather than led growth. In many instances, the very entrepreneurs who started the innovative real-sector enterprises that drove development were the selfsame financial entrepreneurs who established (or assisted in the establishment of) the financial institutions that expanded their commercial and industrial enterprises' access to capital.

One difficulty in sorting out the question of which came first is that financial institutions can assume many and varied forms and follow one of three trajectories: (1) inadequate finance hinders commercial and industrial development; (2) finance emerges endogenously to new demand, accommodates the credit-worthy, and is purely permissive of growth; and (3) finance actively promote endeavors, encourage entrepreneurship, and offers both start-ups and existing firms specialized financial services. One (but not the only) source of disagreement between skeptics and believers is that an economy with many and varied types of financial institutions can simultaneously take on all three characteristics at a given moment, or at different moments or in different places. If an agnostic researcher were to look at one type of financial institution in one place in one time, he or she may arrive at a very different answer to the finance-growth question than the researcher who considers a different institution at a different place at a different time. Besides, the search for one-way causation is fraught from the outset; finance is almost surely "simultaneously growthinduced and growth-inducing [and] what really matter are the character of its services and the efficiency with which is provides them" (Cameron and Patrick 1967, p.2).

Returning for a moment to the historians' study of economic revolutions, Sylla (2002) argues that until recently historians have overlooked what he labels the "Federalist financial revolution." It unfolded in the 1790s and its effects reverberated through the US economy for the next half-century and beyond. Sylla identifies five characteristics of a financial revolution: the development of an integrated network of commercial and other banks; a central bank with nationwide branches; the 
proliferation of competitive financial and nonfinancial corporations; a number of interconnected, integrated securities markets that provide liquidity to securities issued by corporations and governments; and sound governmental fiscal institutions that provide for the provision of essential services, including debt service, without arbitrary and confiscatory taxation. In the US, the groundwork for these five elements was laid in the 1790s (Irwin and Sylla 2011). By the mid-nineteenth century the fruits of the revolution were beginning to be reaped. For a profession weary and generally skeptical of revolutionary moments it is easy to dismiss Sylla's characterization of the Federalist era as a "revolution too many," yet it is undeniable that something very interesting happened in the financial sector in the half century after the Constitutional convention.

This essay reviews the historical finance-growth literature in an American context. Before turning to the empirical evidence on the finance-growth link, the essay first lays out the facts and interpretations of capital accumulation in the nineteenth and early twentieth century. If finance played a role in industrial development and modernization, one obvious channel was through its underwriting investment in private and public physical capital, as well as human capital, so it important to understand how the nature and amount of capital changed over time. Section 3 discusses theoretical approaches to the finance-growth link, and provides a highly stylized characterization of a standard growth model that incorporates the principal functions of financial institutions.

Sections 4 and 5 provide critical evaluations of the existing literature. Section 4 focuses on the connections between commercial banks - the largest group of financial intermediaries in the nineteenth century - and growth. Employing relatively rudimentary data and empirical techniques, the early literature provided equivocal evidence, at best. Explicit investigations of finance and growth that generated equivocal results were consistent with one of the stylized facts of US economic history: the country was not served by an integrated financial market capable of arbitraging on substantial and persistent regional interest rate differentials. This fact cast doubt on the efficacy of finance in the growth process. Any institution incapable of efficiently transferring funds across space was probably unable to transfer across industries. 
A wave of post-1990 studies challenges earlier interpretations. The collection of new data on both finance and macroeconomic accounts and the use of more sophisticated econometric techniques points to commercial banks being relatively efficient in allocating capital and contributing to growth in meaningful ways. Time series and cross-sectional techniques that take statistical identification strategies seriously generate results consistent with the modern finance-growth literature. Growth rates of income, capital accumulation, and urbanization, among others, appear to increase in response to exogenous finance.

Of course the US was served by a wider array of financial intermediaries than commercial banks. Section 5 discusses the historical literature that connects savings banks, private banks and investment banks to long-run growth and development. One basis for skepticism about the finance-growth link is that commercial bank did neither encouraged nor aggregated small household savings into larger pools of investment capital. A specialized intermediary - the mutual savings bank - filled this niche. Savings banks encouraged household saving and then transformed those savings into productive public and private long-term investment. Much of the historical financegrowth literature focuses on how efficiently finance institutions channel a given volume of savings into alternative productive investments. Much less of the literature asks whence the pools of saving, but accumulation is as inherently important as allocation. Investment banks also filled a vital niche left open by the early commercial banks, namely, the provision of external long-term capital used to finance the massive volumes of fixed capital associated with the second industrial revolution. The earliest investment banks tapped into expanding long-term debt markets to finance railroads and public infrastructure projects. Only later did a specialized sub-group of investment banks arise to tap into household savings through the underwriting of equities issued by the multidivisional, multinational industrial and retail firms that emerged in the late nineteenth century. Investment banks were a vital part of the process of economic modernization.

Before moving forward, two caveats are in order. First, in thinking about longrun associations between finance and growth, it is important to assess the importance of a number of different institutions - commercial banks, private banks, savings banks, investment banks, mortgage and insurance companies, and stock markets - 
because historical analysis reveals how changes in information, communication and transportation technologies transform the functional boundaries of the financial firm. Although Coase (1937) was surely considering industrial firms when he developed his theory of the firm, it is equally applicable to financial firms. As economies and nonfinancial firms increase in scale and scope, their financing needs do as well. Innovations in financial firms and practices that worked well in one time and place, say, the rise of commercial banking in the early nineteenth century to finance trade, may not be adequate by itself in another, say, the rise investment banks to place securities issued by Gilded Age-era, multidivisional, multinational, industrial firms. New, more complex financial structures will emerge to deal in new, more complex financial arrangements. It is likely that the increasing complexity of financing arrangements may preclude any single type of intermediary from producing the necessarily wide range of financial services (Snowden 1995). Thus, different types of financial firms may compete in some contexts and act in complementary ways in others. It is not always easy to investigate the synergies between markets and firms, but it is important to keep in mind that they were (and are) in play.

Second, economists comfortable only with evaluating studies based on their satisfying modern conceptions of statistical causality will find much of the economic history literature lacking. But if one is open to the idea of "plausible" causality, the economic history literature offers a wealth of detail that enhances our understanding of the finance-growth nexus (Morck and Yeung 2011; Levine 2005). Good economic history examines the evolution of the legal, regulatory, political, financial and industrial systems of nations, states, and localities to document the connections between financial development and economic growth. In many cases, the studies summarized here run to several hundred pages of narrative history, data construction, empirical analysis and carefully considered conclusions, and any brief description of the principal contribution of each will necessarily fail to provide the details or convey the subtleties of the original. The reader, therefore, will be best served if he or she treats this essay more as an invitation to explore and engage with economic and financial history on its own terms rather than a definitive assessment of key results. Much has been done, but there is much more to do, especially for those with a willingness to make a "serious attempt to get to grips with the facts of history" (Lewis 1955, p. 15). 


\section{Capital, investment, and finance in the early stages of U.S. development}

Economic historians label the nineteenth century the "physical capital" century because, compared to the twentieth century in which society invested heavily in human capital, nineteenth-century Americans invested heavily in public and private physical capital (Goldin 2001). The share of capital formation in U.S. national income increased from about 13\% percent in the decade ending 1843 to $19 \%$ in the decade ending 1888 to 24\% in the decade ending 1955 (Gallman and Howle 1971). Gallman (1992) noted that something was happening in America's pre-Civil War economy. His estimates imply that between 1800 and 1840 the domestic capital stock increased at an average annual rate of about 4\%; between 1840 and 1860 it increased by about $6 \%$ per annum, which was evidence of a pre-Civil War acceleration in economic growth that is also evident in various gross domestic product and national income estimates (David 1967; Weiss 1994; Rhode 2002). The U.S. experience in its formative years of industrial development mirrors most other developed countries in that the onset of modern economic growth was preceded by or at least concurrent with a marked increase in the productive capital stock.

Not only was the aggregate national capital stock increasing in the pre-Civil War era (and beyond), but its composition became more "modern." Before 1840 the nature of the capital stock changed very little, which implies continued exploitation of existing, mostly pre-industrial technologies. After 1840 the share of animals dropped sharply, the share of structures increased slightly, and the share of equipment increased markedly. Gallman (1992, p. 93) interpreted these changes as evidence of "an economy shifting in the direction of industrial activity and modern economic growth."

Such capital accumulation required increased rates of savings and investment the underlying causes of which remained clouded, but Davis and Gallman (1978) offer two potential explanations. Either the investment function shifted in response to changes in aggregate demand or the savings function shifted out relatively due to increased household savings rates. They prefer the latter explanation and offer four potential causes that may have led to a shift in the savings function: (1) a change in 
household preferences toward future over current consumption; (2) an increase in incomes with savings being income elastic; (3) an increase in the returns to savings with savings being interest elastic; and (4) a change in the composition of the saving sector. Davis and Gallman focus on the fourth explanation, arguing that the apparently rapid rise in savings was mostly an increased in measured savings. With the gradual shift of the labor force from rural agriculture to urban commerce and manufacturing, savings changed its form. Where households had previously saved by way of labor invested in eventually marketable farm improvements, urban workers increasingly opted to save by accumulating financial claims in the form of currency, demand and savings deposits, life insurance, mortgages, government bonds, and corporate equities. But for much of the nineteenth century, a typical household's principal claims on the financial system were currency and, in the Northeast, savings bank deposits.

In considering the principal forms of saving and investment, it is useful to think of three Americas: a pre-modern America up to the first half of the nineteenth century; a modernizing and industrializing America of the mid-nineteenth through the early twentieth century; and a modern, post-war America. Realizing the shift in the composition of capital observed in the early nineteenth century required changed attitudes toward the exchange of physical for financial capital. "Traditionally willing only to invest in assets he could touch," write Davis and Gallman (1978, p. 62), "the saver ... gradually became willing to hold scraps of paper representing real assets located as far away in both space and experience." Davis and Gallman believe that these attitudes changed little by little and reached full flower only in the latter half of the nineteenth century after savers had grown accustomed to buying and holding Civil War-era government debt and, still later, railroad bonds. Others contend that the willingness of households to forsake physical assets for scraps of paper came to full fruition only during and after the Liberty Bond drives of the First World War (Ott 2011) or even the stock market boom of the 1920s, which witnessed unprecedented public participation in equities markets (White 1990).

It is not unreasonable to assert that the first flowering of a broad willingness on the part of households to hold paper claims dates to the antebellum era, which witnessed a rapid expansion of the banking and financial system and the systematic 
replacement of specie currency and book ledger credits for banknotes and deposits and, to a lesser extent, equities (Wright 1999; Wright 2002; Wright 2011). Banknotes were (in some cases, quite literally) scraps of paper - symbolic capital - backed by a corporate promise to deliver a physical asset at a future date, which from many rural residents' perspectives was something quite outside their experience.

The rise of an antebellum financial market points to the third of Davis and Gallman's four potential explanations, namely an elastic response to an increase in the returns to savings. Instead of savings taking the form of bonds and equities, it was embodied in money holdings. Few early Americans had the wherewithal to develop a diversified modern portfolio, but they could diversify by holding some combination of real assets and currency. Moreover, currency in the form of a banknote represented a type of derivative security representing a proportional claim on a bank's portfolio. As banks extended their reach and became more reputable, the return to holding banknotes increased (Rockoff 1974). Increases in the real returns to money holding increased the equilibrium stock at every income level. To borrow Shaw's (1973) terminology, the economy experienced monetary deepening.

Shaw (1973) and McKinnon (1973) contend that money holdings and physical capital accumulations were complementary in the early stages of development: conditions that made an increase in real cash balances attractive also encouraged capital accumulation. The Shaw-McKinnon argument hinges on the assumption that nineteenth-century America was a world in which real cash balances were held because bank-supplied currency was the most readily traded financial instrument. Thus, if the desired level of investment increases at a given income, the average ratio of real cash balances-to-income also increased. The emergence of bank and bank-supplied currency, therefore, directly influenced capital formation. Bank-supplied currency performed its dual role as both a medium of exchange and a store of value. Because real cash balances were debt generated in the intermediation process, money holding was not a distinct form of wealth, as in the modern Keynesian approach, but was integral to the process of capital accumulation (Tobin 1958).

A second crucial factor in the mobilization of capital was the emergence of market-determined interest rates after about 1780. Rothenberg (1985) finds that before the American Revolution debt documents rarely reported interest rates. If it was 
charged at all (a debatable point according to Rothenberg), it was reported simply as "lawful interest," usually 6 or $7 \%$ in the colonies. But beginning in the 1780 s interest rates began rising, "floating free of their ancient and customary restraints" (Rothenberg 1985, p. 790). Market-based rates emerged more gradually than might be expected, however. Although Bodenhorn (2007) and Wang (2008) find that midnineteenth century bankers sometimes charged rates in excess of $15 \%$ on loans, the majority were made at the legal and customary rate. Although courts enforced usury limits on loan originations, securities were free to trade in secondary markets at market-determined rates in excess of any usury limit (Freyer 1976). Setting rates free of law and custom made the returns on financial assets competitive with returns on physical capital and made securities an attractive substitute. This simple change was, as Rothenberg (1985, p. 790) notes, "a phenomenon critical to the historical development of capital markets."

To Shaw and other scholars who study the connections between financial and economic development, market-determined interest rates represented a necessary precondition for economic modernization. Low effective interest rates, whether established by custom, law, or religious conviction, made bankers "inert, content to service traditional borrowers and extract [their] monopoly profits from wide margins between low real loan rates and much lower real returns on cash" (Shaw 1973, p. 123). Freeing interest rates from their traditional limits, in addition to the development of a more competitive financial sector, encouraged lending to nontraditional borrowers whose novel projects were riskier than traditional enterprises, but were more likely to encourage industrial innovation and, hence, growth and development (Schumpeter 1934).

Of course, changes in laws and attitudes would have had meant little had financial entrepreneurs not been allowed to take advantage of the new opportunities afforded by these changes. Studies by Sylla (1975), Bodenhorn (2003), and Wright (2002) reveal that nineteenth-century America is best characterized as having adopted free banking, not in the narrow sense of the term as it is used to describe New York's 1838 act and copied elsewhere, but in a more expansive sense that the federalist polity encouraged the states - laboratories of democracy - to experiment with a host of alternative banking regimes. And the first stirrings of financial innovation appeared 
nearly at the founding. The first modern commercial banks were chartered in 1790 s and Alexander Hamilton's plan for the Bank of the United States (1791-1811) influenced the nature of bank chartering for the next half century (Bodenhorn 2011). Sylla, Wilson and Jones' (1994) analysis of early securities markets leads them to argue that a financial watershed occurred around 1815, perhaps earlier. By that date, most every major seaport city had a functioning securities market, which grew increasingly integrated over time (Chabot 2000). The Sylla, Wilson and Jones' dating also accords with rapid expansion of the banking system: 3 banks in 1790; 212 banks in 1815; 584 in 1835. In short, American attitudes and political policies generally encouraged growth in the financial sector. Though there is not unanimity on the issue, there is a large and growing scholarly literature that argues that financial innovation and expansion had a causal effect on capital formation and, ultimately, economic development.

\section{An economic historian's approach to finance and growth}

Raymond Goldsmith (1969) contends that financial development and economic growth followed parallel trajectories in most developed countries. Whereas Goldsmith is reluctant to assign a causal relationship from finance to growth, nineteenth-century observers more readily drew causal inferences. In 1835, New York's bank commissioners wrote:

Banks have justly been esteemed as among the most useful and powerful agents in developing the resources and stimulating the industry of the country. ... [Without them, the country] could not have spread half the canvass which now whitens the ocean, or given motion to half the spindles which are now in operation ... and it is to the increased use of credit in its various shapes during the last half century, that the world is mostly indebted for the astonishing rapidity with which manufacturing, commercial and even agricultural improvements have advanced... (New York 1835).

Not everyone agreed, of course. McKnight (1852) argued that banks were the "props of national wealth and industry, not the foundations of them." The rapid expansion of credit was the result rather than the cause of a growing economy. Given the rancorous debates over banking in the nineteenth century, whether a writer attributed any positive outcome to banks had as much to do with which side of the political aisle they 
occupied as with objective observation. The wide variety of banking experiences made it was easy to find anecdotes consistent with either conclusion.

The debate continues to the present, but rather than charged rhetoric and blunt argument modern approaches adopt formal models and sophisticated empirical techniques to tease out the subtleties of the finance-growth nexus. While modern theoretical models are often complex, the basics of the modern endogenous growth literature connecting finance and growth can be explained using a simple aggregate production function. This characterization is useful as well because it highlights the differences between the Goldsmith and McKinnon-Shaw hypotheses. The two interpretations are not fundamentally at odds; both believed that finance influenced growth, but they emphasize different transmission mechanisms.

Assume that output (y) is a function of capital (k) and a vector ( $\mathrm{x}$ ) of other productive inputs, including labor, natural resources, entrepreneurial talent, and technological change. The functional relationship can be written as:

$$
y_{t}=f\left(k_{t}, x_{t}\right) \text {. }
$$

By totally differentiating, dividing through by $\mathrm{y}_{\mathrm{t}}$ and rearranging terms, we obtain:

$$
\mathrm{dy}_{\mathrm{t}} / \mathrm{y}_{\mathrm{t}}=\left(\mathrm{dk}_{\mathrm{t}} / \mathrm{y}_{\mathrm{t}}\right)\left(\mathrm{df}(\cdot) / \mathrm{dk}_{\mathrm{t}}\right)+\left(\mathrm{dx}_{\mathrm{t}} / \mathrm{y}_{\mathrm{t}}\right)\left(\mathrm{df}(\cdot) / \mathrm{dx}_{\mathrm{t}}\right) \text {, }
$$

which in a closed-economy equilibrium can be rewritten as:

$$
\mathrm{dy}_{\mathrm{t}} / \mathrm{y}_{\mathrm{t}}=\mathrm{s}_{\mathrm{t}} \theta_{\mathrm{t}}+\mathrm{v}_{\mathrm{t}} \varphi_{\mathrm{t}}
$$

where $s_{t}$ denotes the savings rate at time $t, \theta_{t}$ the marginal productivity of capital, $v_{t}$ represents the growth rate in the vector of other factors, and $\varphi_{t}$ the marginal productivities of the other factors. The rate of output growth is determined by four factors: (1) the savings (= investment) rate; (2) the marginal productivity of capital; (3) the growth rate of other productive factors; and (4) the marginal productivities of those other factors. The traditional growth and economic history literatures emphasized the third and fourth terms on the right-hand side, nearly to the exclusion of the first and second. Research focused on changes in the quantity and quality of labor and fixed capital, in addition to total factor productivity growth.

Financial development influences economic growth through either of two mechanisms. On one hand, financial markets may enhance the marginal efficiency of additional capital accumulation (increases in $\theta_{t}$ ), which is the principal mechanism envisioned by Goldsmith (1969) and consistent with Diamond's (1984; 1991) models 
of arm's length intermediation and delegated monitoring. Indirect financing by way of financial intermediaries is more efficient than direct financing because financial intermediaries exploit their informational advantages in allocating funds across competing entrepreneurial projects.

A common thread running through Goldsmith's $(1955 ; 1958 ; 1968 ; 1969)$ and Patrick's (1966) research, both influenced by Schumpeter (1934), is that financial intermediaries positively affect growth by overcoming the low correlations between entrepreneurial opportunities and entrepreneurial resources. The financial system, Goldsmith (1969, p. 400) writes, “accelerates economic growth and improves economic performance to the extent that it facilitates the migration of funds to the best user ... where funds will yield the highest social return." Because intermediaries match savers and investors, banks and other intermediaries are the arbiters of investment, deciding which enterprises are funded and which are not.

Alternatively, McKinnon (1973) and Shaw (1973) focus on increased saving rates $\left(\mathrm{s}_{\mathrm{t}}\right)$. By better matching the risk and liquidity preferences of savers with those of investors, intermediaries that create their own claims and securities increase the aggregate volume of savings (and investment) than economies that rely on personal transactions and directly-placed debt. By McKinnon and Shaw's telling, financial institutions do not upset the economic system in the fashion envisioned by Schumpeter; rather they simply increase the size of the accounts. The total volume of debt and financial securities increases at a faster pace with intermediaries and arm'slength markets than when financing occurs through direct investment or internal finance.

Whether the mechanism is increased efficiency of investment or increased investment per se, intermediation is an important element of growth. Advances in the endogenous growth literature by Bencivenga and Smith (1991), Greenwood and Smith (1997), Boyd and Smith (1996; 1998) and others follow Goldsmith in that they emphasize the role of intermediation in increasing the marginal efficiency of investment by directing resources to their most productive employments. De Gregario and Guidotti (1994) and Gertler (1988), on the other hand, provide models that emphasize the intermediation-led increase in the savings rate. They assume that many investors face borrowing constraints, which limits the potential investor's ability to 
produce at an optimal scale. Unable to operate at optimal scale, entrepreneurs save in the current period to finance next period's investment. Current investment opportunities spur current savings, which increases future investment. Greenwood and Jovanovic (1990) provide a model in which financial intermediaries create both increased savings and increased efficiency simultaneously. Instead of a simple causal mechanism from finance to growth, their model posits feedback loops. Economic growth encourages saving, which increases the size of the financial sector relative to the aggregate economy. In exploiting their information advantages they can better discriminate between competing projects and fund the most promising and potentially productive ones.

Despite the increasing sophistication of the formal models and the empirical approaches that investigate the finance-growth nexus, no consensus has been reached, though the weight of the evidence points toward finance's importance. In some fashion, Kuznets' (1958) characterization of finance as a "social invention ... of people to take advantage of the potentials of economic growth" remains an apt characterization of the conclusion that may be drawn from the modern literature. Zingales (2003), for example, argues that the attention paid to uncovering causal statistical relationships in either time series or cross sectional analyses has obscured the more fundamental question of the channels or mechanisms that may underlay any potentially causal relation running from finance to growth. Studies tend to focus on aggregate measures of finance such as the value of money or credit per capita or per dollar of gross domestic product and concurrent or subsequent GDP growth or aggregate total factor productivity growth (Levine 2005 provides a review). Such studies are valuable, informative, compelling and, sometimes, convincing, but Zingales argues that more satisfying studies would be those that generate measures of financial development that capture the ease with which an entrepreneur can finance a novel project. A developed or, in the case of the U.S. before the mid-twentieth century, a developing financial system is one that provides increasing access to finance at declining costs to a widening groups of participants.

Economic history provides such a large and encompassing tent that it has accommodated both kinds of studies, that is, those concerned with identifying causal relationships between broad aggregates and those that mine micro-level records in 
search for channels and mechanisms. One of the more fascinating, yet frustrating, features of U.S. financial history is the ingenuity of financial entrepreneurs. Albert Gallatin (1831, p. 68), US treasury secretary (1801-1814), real estate developer, and entrepreneur, wrote of the "great difficulties which were encountered by those who first attempted to establish the most necessary manufactures, and that ... the general progress of the country was extremely slow, and might have been hastened" by banks. The history of U.S. finance after Gallatin is the history of an expanding menu of choices available to savers, borrowers, and investors. Commercial banks, private banks, savings banks, investment banks, building and loan companies, trust companies, insurance companies, and securities markets emerged to satisfy unmet demands for finance. It would thus appear that US financial history is one that satisfies Zingales criteria of expanding access, decreasing costs, and widened participation. The remainder of the essay explores how economic historians have approached the fundamental issues at hand: Did the nation's intermediaries funnel the increasing flow of savings into productive, growth-inducing projects? How, if at all, did they modify their operations, subject to the constraints of law and custom, to accommodate new types of borrowers in a developing economy? In short: Did finance matter?

\section{Commercial banks}

"Because of their evident, although quantitatively indefinable, role in the provision of investment credit, the increase in the number of commercial banks and in their [banknote] issues and deposits becomes a primary datum in economic growth."

Stuart Bruchey (1965, p. 147)

Bruchey's observation reveals two features of the economic history of banks and banking prior to the 1970s: there was a supposition among some historians that they were growth-enhancing; and virtually no quantitative evidence had been brought to bear on the question. In the interim a sizeable empirical literature has emerged that generally supports the contention that banks contributed to growth. Whether they were one of many causal factors is less clear, though a growing body of literature points to that conclusion. 


\subsection{First-generation approaches and framing the debate}

Any discussion of the finance-growth nexus for the early U.S. must start with a discussion of commercial banks, which, measured by assets relative to national income or any similar metric, were by far the largest formal lenders into the twentieth century. Despite their combined size and special nature, many economic historians writing in the 1960s and 1970s had reservations about whether banks made meaningful contributions to development, which was attributed more to industrialization and innovation than intermediation. Because commercial banks preferred to lend at shortterms and to reputable, established borrowers who discounted mostly high-grade 60and 90-day paper, banks seemingly offered relatively little long-term credit for fixed capital investment or even short-term funds to young, innovative enterprises. As Adams (1975, p. 219) states, banks were believed to contribute to growth to the extent that intermediation moves away from the financing of purely commercial transactions "in favor of acquiring long-term, less liquid assets often associated with the acquisition or improvement of land, the development of manufacturing, or the growth of social overhead capital." Because there was little evidence that banks engaged in such practices, it was easy to downplay banks' importance.

Not everyone agreed, however. Cameron and Patrick (1967) argued that too much was made of commercial banks' provision of short-term working-capital rather than financing for fixed capital. Apart from overlooking the many instances in which banks did not adhere to the philosophy, the traditional interpretation fails to account for the ways in which entrepreneurs, including industrialists, used bank-supplied shortterm credit to free up their own resources for fixed investment. In the early stages of development, fixed capital needs were often small relative to working capital so that external finance was not as critical to early industrial development as it would be a century later (Pollard 1964; Sokoloff 1984).

Banks sometimes contributed to economic modernization through their support of infrastructure rather than industry. The Canal Bank of New Orleans, Louisiana built a canal between Lake Pontchartrain and central New Orleans; the Gas Light and Banking Company constructed and operated a half-million dollar urban light 
system. The Commercial Bank operated the city waterworks. Two other banks built and operated hotels (Green 1972). Adams (1975) finds that Ohio's banks were heavily invested in that state's ambitious canal-building program. Golembe (1952) estimates that, during the antebellum era, banks in the Old Northwest supplied about one fifth of the approximately $\$ 40$ million spend on canals and other internal improvements. Even in eastern states, banks contributed toward bridges, dry docks, city water systems, railroads, and other investments in social overhead capital. Investments in transportation and other improvements increased the efficiency of complementary capital, including manufacturing capital. Green (1972, p. 112) contends that the objective of the era's political leaders in chartering and subsidizing these so-called improvement banks "was always to promote economic development," but the question remains whether the banks they chartered moved their economies closer to some optimal pattern of development.

Early empirical studies concerning the finance-growth nexus relied on the McKinnon-Shaw models of financial development, which argued that a fundamental feature of a financially sophisticated economy was the extent to which transactions were made with bank money. McKinnon and Shaw argued that developing economies with under-developed financial markets tend to have bank money-income ratios of about 0.10; moderately developed economies with functioning financial markets have money-income ratios closer to 0.30. Using Easterlin's (1960) conjectural state-level average income estimates, Adams (1975) finds that the money-income ratios in the antebellum Old Northwest declined from 0.11 in 1840 to 0.09 in 1860, which points toward a financially underdeveloped region and one in which banks failed even to keep up with development. ${ }^{1}$

Rockoff (1975) estimated state-level money-income ratios for 1840, with a national average of 0.12 and ranged from a high about 0.20 in Rhode Island and Massachusetts to a low of 0.03 in then frontier Missouri. Lacking income estimates for 1850 and 1860, Rockoff turned to wealth estimates from the 1850 and 1860 censuses

\footnotetext{
1 By way of comparison, Rousseau and Wachtel (1995) report a bank money-to-income ratio for the U.S. that increases from about 0.20 in 1880 to 0.55 in 1990. It exceeded 0.70 briefly in the late 1920 s and again during the Second World War. The Rousseau-Wachtel estimates will be lower than the ratios reported by Adams (1975) and others because Rousseau and Wachtel's ratio is bank money less high-powered money divided by income. Most historical studies calculate the ratio without subtracting high-powered money in the numerator.
} 
to calculate money-wealth ratios for the later years. Although he does not conduct a regression analysis, he reports his data in an appendix, which can be used to estimate a relationship between a measure of financial development and subsequent growth. The scatterplot presented in Figure 1 reveals a modest but statistically insignificant positive relationship between the initial money-income ratio and subsequent growth in state average per capita wealth. The results are consistent with Rockoffs (1975, p. 177) conclusion that the evidence provides little support for the proposition that the "liberalization of the capital markets promotes financial and economic development."

\section{Figure 1}

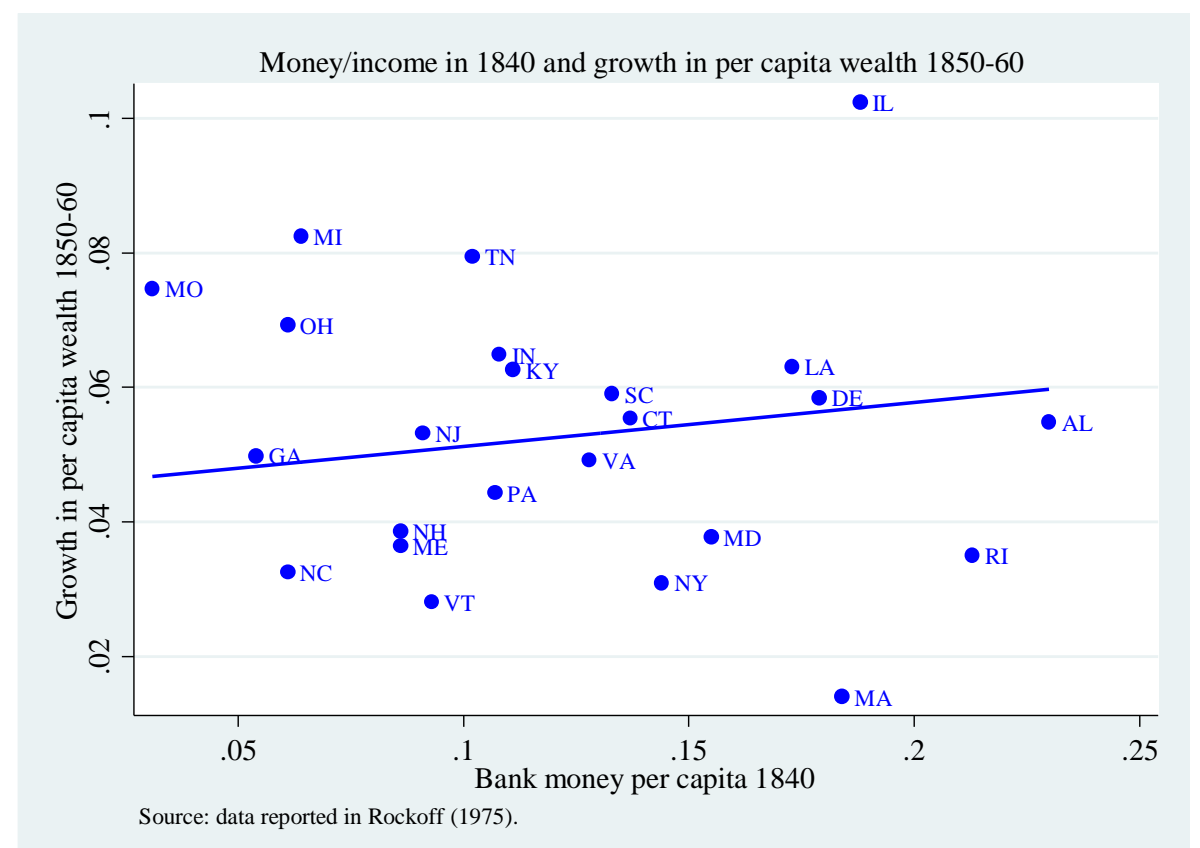

Green (1972) investigates the finance-growth nexus in antebellum Louisiana from a McKinnon-Shaw-Goldsmith perspective. Louisiana merits independent analysis because New Orleans was the second-busiest US port in the antebellum era and was subject to four distinct banking regimes: traditional chartered banking up to about 1830; a system of state-subsidized improvement banks in the mid-1830s; a period of conservative retrenchment in the early 1850s; and a period of liberalized entry, but heavily regulated banking up to the Civil War. Green collects banking data 
for the entire period and, using estimates of cotton production, sugar production and commercial trade, creates annual state-level real income estimates. His estimates reveal a rising bank money-income ratio between the early 1820s and the mid-1830s, by which time the ratios $(\approx 0.40)$ date reach values seen in moderately developed economies. ${ }^{2}$ The ratios fall during the recession of the late 1830 s and early 1840 s and remain around 0.25 to 0.30 through the remainder the antebellum era.

Green (1972) contends that the state's banks promoted economic growth by encouraging increased saving and redirecting it from consumption to investment, that is, through both mechanisms discussed previously in Section 2. He concludes that early Louisiana is an example of finance-led growth, but the post-1839 recession experience tempers his conclusions. "It is possible," he writes, "that Louisiana's growth might have been greater than it actually was if the financial system had been more expansionary" in the 1840s and 1850s. Although Green eschews formal statistical analysis, a regression of real per capita income on the money-income ratio, corrected for autoregressive errors, reveals a negative, though statistically insignificant relationship driven largely by the state's excessively conservative post-1840s recession banking laws. The restrictions caused a gradual decline in money-income ratios despite rising real incomes. Green attributes the relative stasis of the late-antebellum and early postbellum New Orleans economy to the redirection of produce trade away from New Orleans to other port cities as a consequence of the railroad replacing river transport and the inability of the state's banks to meet the credit demands of produce traders.

Early studies in the McKinnon-Shaw tradition, therefore, provide less than compelling evidence in favor of the finance-growth nexus in the developing, early nineteenth-century U.S. Sylla $(1967 ; 1975)$ argues that the finance-growth link was operative, but worked through a channel - interbank balances -- other than increased monetization. The interbank or correspondent market emerged in the antebellum era, but became a defining feature of US banking only in the national banking era (Myers 1931; Bodenhorn 2000).

\footnotetext{
${ }^{2}$ Green (1972, Appendix) believes that his income estimates capture about $60 \%$ of actual income. The moneyincome ratios reported here differ from his because the income estimates are inflated to account for Green's estimate of his undercounting of income. Doing so makes his figure comparable to others reported elsewhere.
} 
Sylla (1967) notes that between 1865 and 1913 per capita real output and industrial production grew at modern rates despite four financial panics and the operation of a national banking system that hamstrung the banking system through entry barriers, aggregate note-issue limits, tying note issues to federal fiscal policies, and restrictions on the size and types of allowable loans. He argues that one unintended consequence of the national banking system's regulations was that the nation's rural banks contributed to industrial growth. Restrictions that limited competition and regulated lending in conjunction with the rule that allowed country bankers to count interbank balances held with large city banks as reserves against bank-created money encouraged the development of active correspondent relationships. Country banks, many of which held local monopolies, remitted their excess reserves to their urban respondents who invested the interbank balances in the call loan market. The amassing of large sums in the call loan market, in turn, increased liquidity in equity markets, which encouraged capital formation through new equity and debt issues. Railroads and industrialists building modern multi-divisional, multinational, hierarchical firms that exploited economies of scale made possible by a widening national market benefitted from access to liquid equity and debt markets (Chandler 1977). "If there was a defect in the postbellum American banking system," writes Sylla (1972, p. 258), "it was not that it hindered long-term economic development, but that it promoted industrial development and growth with a ruthless efficiency" at the expense of agriculture and the rural sector.

Although a number of subsequent studies accept Sylla's conclusion, not all do (see, for example, James 1976). Cameron (1972) believes it important to determine the net effect of the growth-inducing effects of the interbank market on industrial finance from its growth-reducing effects on agriculture and small-town, small- and mediumsize enterprises unable to access local capital. Updike (1985) questions both the extent of the country bank's monopoly power and, therefore, the reduction in local lending as a result of the monopolist's profit from the restriction of output, as well as the city bankers' unwillingness to forego higher hinterland rates and to compete with country bankers for local loan business. But Updike's discussion fails to appreciate the information-intensive nature of lending in the hinterlands, which requires local knowledge. Thus country bankers' markets were protected, at least to the extent that 
information costs exceeded city-country interest rate differentials. Campen and Mayhew (1988) provide a case study of Knoxville, Tennessee in which they find that prior to the city's emergence as a regional node in an expanding rail network, the city's banks behaved as Sylla argued they would; only 37\% of their assets were invested in local loans. But readier access to distant markets resulting from the addition of new railroads into the local node encouraged growth in the regional mining and manufacturing sectors, which only then encouraged the entry of new banks and the expansion of existing ones. From this, they conclude that the "causal chain" ran not from banks to growth, but from growth to banks. It is easy to consider a case study that contradicts the results of aggregate studies as outliers or anomalies, but it raises enough questions to temper either conclusion concerning a finance-growth link.

Lance Davis' $(1963 ; 1965 ; 1966)$ interpretation of bank's marginal and indirect contributions to growth largely carried the day. He reports several notable instances of commercial banks' unwillingness to assist modernization, which buttressed his larger conclusions about the immobility of capital (discussed below). Late nineteenth century Southern textile mill managers complained that banks refused to discount their notes. When meat-packing giant Philip Armour opened a packing house in Kansas City in 1869 and was unable to obtain finance from local lenders, he set up his own bank, the Armour Brothers Banking Company to provide his Kansas City affiliate with finance. To assure greater access to capital in Chicago, he arranged to have associates elected to the boards of most of Chicago's major banks who then used their insider status to encourage banks to lend to Armour. When technological developments in the 1870 s increased the minimum efficient scale of oil refining, Cleveland's bankers turned away most of the applicants, considering the emergent refining industry too risky. No small part of John D. Rockefeller's success in building and keeping a large refinery running followed from his having enlarged his circle of friends and associates to include representative of New York City's large banks. If the anecdotal evidence is to be taken at face value, it appears that at least three industries associated with the industrial revolution found banks reluctant to provide them with finance, even short-term commercial finance. Davis' (1965) interpretation -- early financial markets did a relatively poor job of allocating credit across sectors and geographical space -emerged as one of the stylized facts of the new economic history. 


\subsection{Regional interest rate differentials and the finance-growth link}

In the 1960 s and 1970 s a vibrant literature investigated regional interest rate differentials and provided apparently compelling evidence of banks and other financial intermediaries unable to mediate between savers and investors in the face the rapid growth in the nation's territory, population, and economic activity. Late-nineteenth and early-twentieth century observers recognized that regional interest rates in the U.S. exhibited dramatic differences and found little evidence that of narrowing regional spreads (Breckinridge 1898).

Davis's (1965) observation that late-nineteenth-century US deviated from the neoclassical, perfect competition model of resource allocation in which mobile capital, given allowances for risk, uncertainty and transaction costs, would equalize returns across regions and sectors. In the early stages of development, he argued, uncertainty (as distinct from risk) discounts would be sufficiently high so as to impede capital flows (Knight 1921). The resulting differentials in borrowing rates could and probably would slow growth in potentially high-growth sectors and areas. Economic development was a process whereby uncertainty discounts were reduced, if not eliminated, making it possible for capital to flow freely between regions and sectors. The role of intermediaries in reducing these discounts is paramount and takes centerstage in Davis's subsequent interpretations of economic development in the US and elsewhere (Davis 1966; 1978; 2001).

The post-1880 lines in Figure 2, which plot three-year moving averages of annual estimates of regional bank lending rates (as proxies for average regional shortterm interest rates), reveal that U.S. loan markets were not characterized by uniform national rates. Fifteen years after the Civil War and 15 years into national banking, rates outside the Northeast were two to four percentage points higher than rates in the Northeast. By about 1920 the regional gaps had narrowed, but even as late as 1960 there still remained a roughly one-half percentage point difference between the Northeast and the rest of the country. 
Figure 2

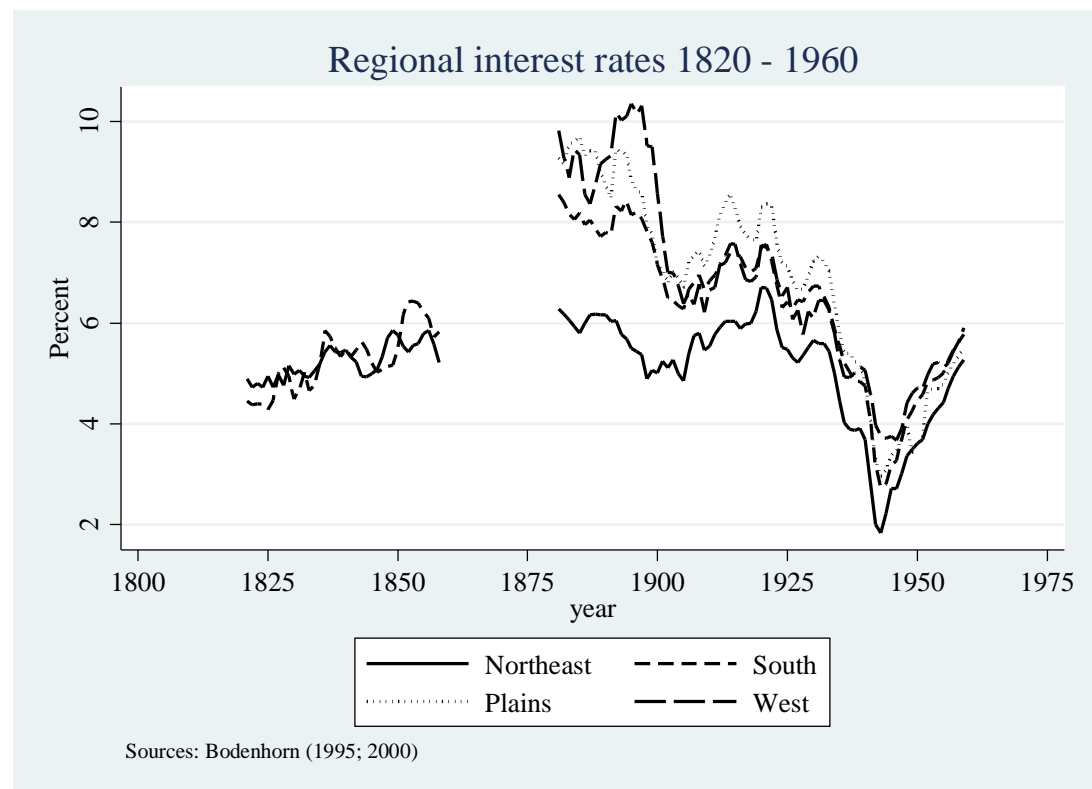

Davis's revelation sparked a three-decade long debate about the causes, consequences, and implications of the initial rate gap and their narrowing. At the risk of eliding over some subtleties, the participants in this debate attributed the differentials to one of four factors: (1) an extreme home bias or provincialism in investment preferences that militated against arbitraging on rate differentials (Davis 1958; Davis and Payne 1958, p. 404); (2) inadequate information, financial and transportation infrastructure that raised transaction costs and impeded the flow of capital across regions (Davis 1968; Olmstead 1976); (3) regulatory impediments to the geographic mobility of capital (Sylla 1969; James 1976; Davis and Gallman 2001); and (4) differences in the riskiness of investment across regions (Stigler 1967; Eichengreen 19xx; Bodenhorn 1995). By 1980 or so the debate was sufficiently balkanized that the only point of agreement between the home-bias and differential risk camps was that regulation probably impeded at least some capital flows. 
This debate and its resolution bears directly on the finance-growth relationship. If the source of the persistent regional differentials was provincialism or the "disinclination of capital to migrate," the regional rate gaps reveal a principal financial sector participant - the commercial bank - that labored mightily and not always successfully to overcome the strains placed on it by a changing geographic and industrial mix of production in the late nineteenth and early twentieth century (Davis 1966). A banking system incapable of conquering space was unlikely to conquer new industrial structures. Even today, when "funds can flow freely from place to place, the quality of local intermediaries will continue to matter" because distant investors rely on local intermediaries to traverse the "last mile" of information gathering and monitoring (Guiso, Sapienza and Zingales 2004a, p. 967). Local intermediaries help transform uncertainty to risk and facilitate the transfer of capital to start-ups and other small- and medium-size enterprises. Knitting regional banks into a national network is an important element of financial development.

Geographically segregated capital markets, likewise, will lead to inefficient investment choices by investors and savers. In fragmented markets, transactions occur absent accurate prices. As a result, transportation, communication, and industrial firms respond to rates of interest that may not reflect the true cost of capital, which interferes with its efficient sectoral employment. Davis (1960), for instance, posited that one reason why the textile industry emerged in the northeastern US was because the relatively low cost of capital more than compensated for the costs of paying higher wages and moving the raw cotton out of a high-interest rate South. It was only after textile firms could rely on a combination of trade credit and self-finance in the $1890 \mathrm{~s}$ that they moved south to take advantage of relatively low-cost labor and proximity to their raw material. Thus, understanding the knitting together of a national financial market is crucial in understanding the temporal and spatial distribution of commerce and industry more generally.

A series of studies in the 1990s offered some resolution (Rockoff 1990; Bodenhorn 1992; 2000; Bodenhorn and Rockoff 1992). These studies turned to the antebellum era, when bank chartering was more liberal and regulation was less onerous, and found that any pre-Civil War differentials were small compared to the postbellum era. Figure 2 plots the regional average bank lending rates for the 
northeastern and southern US (the Plains and Far West regions were not yet sufficiently populated or banked to generate comparable measures). It is readily apparent that any prewar differentials were small. Because banks in each region specialized in discounting double-name paper of roughly comparable risk Rockoff (1990) and Rockoff and Bodenhorn (1992) conclude that postwar rate gaps were attributable mostly to national banking era regulations. Further, they suggest that it may be useful to think about the nineteenth-century frontier as the line separating regions integrated into labor, product and capital markets and those not yet so.

So what forces brought about the narrowing of regional gaps after the war? Both Davis (1966) and Sylla (1969) argue that the rapid westward postwar movement of population and economic activity required the creation of new institutions that could overcome regulation-induced capital market frictions. Davis's (1966) explanation focused on the commercial paper market, which was an institution that came into being largely to arbitrage on regional differentials. One of the more puzzling features of the commercial paper market, however, is that it fell into decline in the 1920s, or at about the time markets became integrated. Phillips and Cutler (1998) argue that an active secondary market for bank drafts moved funds around the country. Sushka and Barrett (1984) argue that the financing decisions of big business became increasingly interest elastic, which pushed them into equity finance. Odell (1989) argues that rate convergence occurred at the regional level. Once regions became internally integrated, links between regional money-center markets integrated into the national market.

Though Sushka and Barrett disagree, Bodenhorn (1992), James (1995) and Phillips and Cutler (1998) consider the elimination of regulatory barriers as the root cause of regional rate convergence. Bodenhorn (1992) and Phillips and Cutler (1998) show that while the market for bank drafts (domestic exchange) transferred funds across state and regional border for a century, it fell into decline with the establishment of Federal Reserve's Gold Settlement Window in 1918 that transferred funds without charge. The Fed's zero price drove private firms from the market. James (1995) contends that the commercial paper market's decline was concurrent with the rise of large money-center banks that could meet the short-term credit requirements of modern industrial firms. The informational advantages of bankcustomer relationships better served many industrial and commercial firms than arm's 
length commercial paper markets. The rise and fall of the domestic exchange and commercial paper markets is then consistent with Sylla's (1972) observation that regulatory barriers interfered with the banks' intermediation functions; freed from binding regulatory impediments, the nation's commercial banks allocated capital across space with such "ruthless" efficiency that they nearly drove one institution from the market.

The postbellum mortgage market was less integrated than the commercial bank loan market, which surely influenced migration, residential investment, and farm making costs. Building and loan societies emerged in the mid-nineteenth century, and were successful in assisting working-class families to buy their own homes. In 1850 the residential housing stock represented $19.4 \%$ of national reproducible tangible assets; in 1900 it had grown to $25.5 \%$, due in part to the nearly 6,000 building associations with about 1.5 million members (Dexter 1891; Potter 1954; Carter et al, 2005, series Ce233238.). In 1920 building association accounts represented $15.5 \%$ of national savings, but for a number of reasons they were decidedly local institutions that generally eschewed mortgage investments far removed from their home markets. Some limited their lending to a few city blocks; others to no more than 50 miles from the association office. One reason for their home-bias was the difficulty in gathering quality information on distant properties and monitoring homeowners' behaviors before and after the loan. A second, perhaps, and perhaps more important reason, was that building associations tended to managed by builders, real estate professionals, and attorneys who used the associations to finance their own projects (Snowden 1995a; 1995b; 1997).

The result was that, between 1870 and 1940, mortgage credit costs varied dramatically across regions. Mortgage rate differentials reflected imbalances in regional and local supplies and demands for mortgage credit and persisted because building associations were reluctant to move funds across space (Snowden 1987; 1988). Snowden's analysis offers some specificity to Davis's (1965) assertion that funds failed to move due to information and risk costs. The real issue, however, was that it was difficult to structure optimal agency contracts in a way that would have encouraged eastern savers to finance prospective western land- and homeowners. Specialized 
mortgage companies arose in two periods in the late nineteenth century, but both ended with waves of mortgage defaults and mortgage company failures.

Even though a considerable amount of ink has been spilled on the extent, causes, and nature of regional interest rate differentials, less attention has been paid the question of whether and how postbellum regional rate differentials directly influenced the spatial distribution of capital than it merits. This might be a fruitful line of future inquiry.

\subsection{Second-generation studies of the bank-growth nexus}

Despite the apparent failure of postbellum banks to mobilize funds across space and the equivocal results from the first-generation finance-growth stories, the question is one of continuing interest to economic historians. Since about 1990 historians have brought to bear a variety of archival and empirical approaches, and pursued answers to the question from a variety of perspectives.

Skeptics of the finance-growth hypothesis continue to point to the fact that U.S. commercial banks generally failed to offer long-term credit to manufacturing and industrial firms, which was needed to acquire the heavy capital associated with economic modernization (Hammond 1957). Cull et al (2006) contest this critique. Because financial capital is fungible in many instances, so long as firms have access to some form of external finance, the particular form it took - debt versus equity, shortversus long-term - does not appear to have mattered much. Industrialization progressed apace in nineteenth-century New England despite firm's limited access to equity finance or long-term bank credit. The more capital-intensive machine tool, electrical and automotive industries that emerged in the late-nineteenth-century Midwest received little support in the form of long-term debt from commercial banks (Lamoreaux, Levenstein and Sokoloff 2007). In both New England and Cleveland, firms made due with a combination of short-term bank finance, trade credit, and private equity.

Lamoreaux's (1986; 1994) detailed archival studies of banks in Rhode Island and Massachusetts reveal how aspiring manufacturers and other entrepreneurs could make commercial banks work for them. In these states bank charters were relatively 
easy to obtain and many entrepreneurs organized banks managed by small groups of businessmen related by blood, marriage or established business ties. The banks then loaned the bulk of their funds to their own managers and directors, or other associated with the managers and directors. New England's insider banks were, in effect, the financial arms of wide-ranging, kinship-based enterprises, not unlike banks inside Japanese keiretsu. It was well known that these banks directed most of the bank's loans to insiders, which raised the specter of tunneling and other forms of expropriating minority shareholders. Yet the region's insider banks found locals ready to invest. Potential investors were relatively unwilling to invest directly in these groups' manufacturing enterprises, but they readily purchased minority stakes in the groups' banks. The ability to tap outside pools of capital then allowed the groups to expand beyond the financial capacity of its individual members. Bank shares were attractive because they represented a share in the "diversified investments of their community's most active entrepreneurs" (Cull et al 2006, p. 3026). Moreover, the range of businesses financed through insider bank lending was as varied as New England's economy: international and domestic trade, whaling, textiles, lumbering, manufacturing, and others.

Lamoreaux and Glaisek (1991) report that the majority of directors of banks organized in Providence, Rhode Island after 1830 were men of modest means compared to directors of the older, established banks. But control of a bank allowed them to tap into local savings to invest them in their own and other emergent enterprises. By 1845, the new banks' directors' taxable wealth exceeded that of the old banks' directors. Rhode Island's liberal and permissive bank chartering policies, then, afforded an incipient entrepreneurial class to respond in true Schumpeterian (1931) fashion. Capital was redirected from traditional to then-modern sectors, which fostered a business and regulatory culture amenable to economic change and development.

Bodenhorn (1998; 1999) and Wang (2008a; 2008b; 2016) provide detailed micro-level studies of individual banks in Watertown, New York and Plymouth, Massachusetts. Although manufacturing represented about $15 \%$ of all firms in Watertown in the 1850 s, Bodenhorn finds that manufacturers received nearly $25 \%$ of all loans, and loans to manufacturers were about $60 \%$ to $70 \%$ larger by dollar value 
than loans to merchants. Wang finds that, although merchants received the majority of the banks' loans, artisans and manufacturing captured an increasing share from early to mid-century. Where manufacturers received about 3\% of loans extended by a Plymouth bank between 1803 and 1833, manufacturers received 26\% of all loans between 1843 and 1849. It was not essential that banks lend to manufacturers for them to have promoted growth in the mid-nineteenth century, but it is notable that these two banks did, and there is no reason to think that Watertown or Plymouth were atypical places or that these were atypical banks. ${ }^{3}$ The northeastern US was dotted by small and medium-size towns populated with small and medium-size firms served by small- to medium size banks.

Evidence of the finance-growth nexus does not rely only on narrative or micro-archival approaches. A host of other studies exploit recent additions to our understanding of economic development and recently collected data to econometrically investigate the nexus. Bodenhorn (2000) builds on the earlier literature connecting monetization with the stirrings of economic growth in the pre-Civil War era and the King and Levine (1993a; 1993b) approach. He regresses initial moneyincome ratios on subsequent estimates of state-level income growth and finds a positive relationship: a $10 \%$ increase in the initial money-income ratio is associated with an increase in state income growth of about eight-tenths of a percentage point, or the equivalent of moving from an average slow-growth state to an average fast-growth state in the 1850 s.

Section 3 posits a connection between finance and physical capital accumulation. Using county-level data in the late antebellum era, Jaremski and Rousseau (2013) estimate that, despite banks' supposed unwillingness to finance heavy capital, a $10 \%$ increase in the number of banks is associated with 1.1 to $1.9 \%$ greater subsequent growth rate in manufacturing capital. A $10 \%$ increase in bank loans is associated with a 0.6 to $0.7 \%$ increase in manufacturing capital. Jaremski (2014) uses both county- and firm-level data to investigate the connection between the entry of 729 national banks in the upper Midwest between 1863 and 1866 and manufacturing activity. Among counties that gained a bank in this period, $13 \%$ of the growth in the county's manufacturing per establishment can be attributed to the new bank.

\footnotetext{
${ }^{3}$ Wright (1999) reports similar responses of bankers to modernizing local economies.
} 
Establishment-level increases in the use of steam engines are also positively associated with the establishment of new banks. These are among the first studies to formally link increases in physical capital with increases in financial services in the mid- and late-nineteenth century. Though eminently plausible, the Bodenhorn-JaremskiRousseau results are suggestive because none can be viewed as statistically causal because it is not clear that initial finance is genuinely exogenous.

In a series of related studies, Rousseau (2003) and his coauthors (Rousseau and Sylla 2003; Rousseau and Sylla 2005; Rousseau and Wachtel 1998; and Wachtel and Rousseau 1995) employ modern time-series econometrics, including vector autoregressions (VARs) and vector error correction models (VECMs), to study the connection between a number of financial and real-sector realizations in the U.S. and elsewhere. These studies provide support for the finance-growth nexus in that the results imply that financial variables Granger-cause output, but output does not Granger-cause finance. In general, a $1 \%$ increase in finance leads to a 1.3 to $1.5 \%$ increases in output over the subsequent five years. In evaluating these studies it must be kept in mind, of course, that Granger causality is not causality as the term is currently used in empirical economics. It is also important to recognize that timeseries approaches impose functional forms that generate rapid rates of adjustment to innovations in finance. Changes in finance, however measured, tend to manifest themselves in changes in real economic activity in three to five years. Economic historians, however, tend to think that the true effects are more likely to play out over decades rather than years.

Rousseau (2003) further points out why testing the finance-growth hypothesis in developing economies is a sometimes fraught enterprise. Agriculture remained the dominant source of income for most of the nineteenth century and employed a large fraction of the labor force into the twentieth century. Measures of gross national product such as those constructed by David (1967), Berry (1988) and Weiss (1994), therefore, are driven mostly by increases in agricultural productivity rather than growth in the modern sector, or that part of the economy that relied on finance. Instead of trying to overcome this problem, Fulford's (forthcoming) analysis exploits the importance of agriculture in the late nineteenth century to establish the finance-growth link. He takes advantage of minimum capital requirements at national banks 
determined by local population, which creates a discontinuity to identify the effect. His results reveal that, for the marginal county, the establishment of a minimum-capital bank increases agricultural output by about eight percent, mostly by bringing more land under cultivation rather than through more intensive use of land. He hypothesizes that even though commercial banks were precluded from lending to farmers on mortgage, the presence of a bank shifted production toward geographic comparative advantage. One issue with Fulford's strategy is that it ignores state banks. In the period Fulford studies, states were reducing minimum capital requirements and other regulations to encourage the entry of small-scale banks into less populous localities (White 1982; 1983).

Given the difficulties of generating accurate income estimates at the state or local level, some historians have turned to alternative measures of modernization to explore the finance-growth connection. Jaremski and Rousseau (2013) and Bodenhorn and Cuberes (2010) both attempt to link the organization or prior existence of commercial banks with subsequent urbanization, which they argue serves as a reasonable proxy measure of modernization. Jaremski and Rousseau regress the number of banks and the dollar value of bank loans at an initial date with subsequent increases in the proportion of county residents residing in an urban area. They find that a $10 \%$ increase in banks in 1850 is associated with an $0.3 \%$ increase in urbanization in the following two decades. A $10 \%$ increase in the dollar value of bank loans in 1850 is associate with an $0.1 \%$ increase in urbanization. Bodenhorn and Cuberes (2010) attempt to exploit the political, rather than economic, allocation of banking facilities in the early US to identify whether the presence of a bank leads to subsequent population growth at the town or city level. OLS and propensity score matching estimates imply that the establishment of a bank prior to 1840 increased population growth between 1840 and 1870 by 1.3 to 1.6 percentage points.

Whereas first generation studies recognized that banks contributed directly to or otherwise subsidized the construction of much-needed transportation infrastructure, including turnpikes, bridges, and canals, Atack, Jaremski and Rousseau $(2014 ; 2015)$ use modern methods to tease out the virtuous circle of growth-inducing behaviors for banks and railroads after the mid-nineteenth century. Not surprisingly, early railroads connected already substantial cities and towns, like Boston and Albany, 
in which one or more commercial banks already operated. Atack et al (2014, p. 946) find that new banks sprung up along the rail lines in previously isolated and remote places so that the building of rail lines, thus, filled in "the banking map more rapidly than would have otherwise occurred." Small towns evolved into regional financial, commercial and manufacturing centers. Bodenhorn and Cuberes (2015) identify a similar pattern of banking development along New York's Erie Canal. The canal widened the marketplace not only for goods and finance, but for ideas and innovation as well in that Sokoloff (1988) found that patenting activity increased markedly in counties adjacent to northeastern canals. But Atack et al's (2015) study suggests that railroads squared the virtuous circle by making local loans less risky. Although postrailroad banks held more loans and fewer government and corporate bonds, which means that they directed a larger fraction of their assets to local borrowers with obvious growth-enhancing implications, these banks failed at lower rates. One plausible explanation is that rail connections provided wider, more stable markets to local producers, which had the beneficial side-effect of creating more stable local financial institutions.

Dehejia and Lleras-Muney (2007) note that while a large literature connects financial development with economic growth in the late twentieth century, the mechanisms that underlay the connection are less well understood. The same can be said for the bank-growth connection up to the mid-twentieth century US. They argue that two regulatory changes may provide some insights: branch banking and deposit insurance. Branch banking should have an unambiguous positive effect on growth because, as Schweiger and McGee (1961) found, branch banks mobilize more local savings per dollar of income and offer more loans per dollar of deposits than unit banks. The growth inducing effects of deposit insurance, on the other hand, are less clear. Deposit insurance may increase bank leverage and therefore bank credit. But if banks respond to the insurance subsidy by making riskier loans to less productive enterprises, the growth-enhancing effects will be mitigated.

Using a generalized difference-in-differences approach, Jayaratne and Strahan (1996) were the first to test for the branch banking effect and find that the relaxation of branching restrictions in a treatment group of states is associated with an increase in real per capita state income growth compared to a group of control states. They also 
show that the channel is primarily through lending quality. Branch banks do not necessarily lend more; they lend better, which improves the efficiency of investment. Dehejia and Lleras-Muney's (2007) results are consistent with this result. They adopt a variety of strategies to address endogeneity, and they find improved yields in agriculture and more manufacturing activity. Deposit insurance, on the other hand, is associated with reduced agricultural and manufacturing output. Given that several US states experimented with branch banking and deposit insurance as early as the early nineteenth century, modern studies point to potentially valuable lines of inquiry into whether and how alternative nineteenth-century banking structures induced growth. Their results also reflect on debates within economic history and accord with arguments that banks are reasonably efficient at allocating credit to the extent that regulations are not overly restrictive.

\subsection{What do bank failures tell us about the bank-growth nexus?}

As the three previous sections make clear, there is a large and diverse empirical historical literature that explores whether and how financial development facilitates investment and, ultimately, economic growth. Because banks and other intermediaries mitigate moral hazard and adverse selection problems that increase the costs of raising external funds, functioning financial markets should disproportionately benefit firms mostly small and medium-size firms -- most dependent on external finance (Kroszner et al 2007). One recurring issue in the historical literature is establishing statistical causality. Regressing initial finance on subsequent growth will not solve the problem if aspiring bankers had enough foresight to locate in regions likely to experience higher rates of industrial development and economic growth. And at the state or local level, initial finance is likely to be the consequence of what Bordo and Rousseau (2006) label "deep endogeneity," or the cultural, political, religious, economic, institutional and other factors likely to influence financial development in the long run. Plausible instrumental variables are in short supply, panel estimates subsume most of the interesting variance in the fixed effects, and time-series analyses generate Grangercasual but not genuinely causal estimates. 
The search for plausibly exogenous changes in banking activity has led a number of scholars to consider the short- and long-term consequences of financial panics. Although panics sprang up about once a generation prior to the postwar era, their appearance in a particular locality was plausibly exogenous (Wicker 1995, 1999; Reinhart and Rogoff 2011). The logic underlying these studies is, as Kroszner et al (2007) note, that if banks are the key financial intermediary that serve firms unable to tap into arm's-length markets, an unanticipated negative shock to intermediaries should have a disproportionately negative effect on sectors and regions dependent on bank services.

Irving Fisher (1933) was the first to recognize the connection between the decline in financial intermediation and negative short- to medium-term growth. Fisher's "debt-deflation" theory is developed from a series of logical connections: borrowers become highly levered during economic expansions; an unanticipated downturn leads to borrower bankruptcies, which leads banks to reduce their lending; the pull-back by banks leads to deflation, which redistributes wealth from borrowers to lenders; the decline in borrower net wealth leads to more bankruptcies, which further reduces economic activity. Such downward spirals can persist for short periods as in a standard recession, or for longer periods as in the Great Depression or Great Recession. Banks and their joint lending-money creation activities are thus central to Fisher's explanation.

Friedman and Schwartz (1960) and Bernanke (1983) provide detailed empirical and narrative studies of banks and growth in the Depression era. Friedman and Schwartz emphasized the connection between bank failures, the decline in the money stock, and the economic downturn. Bernanke's (1983) classic study focused on debtoverhang and nonmonetary channels contributing to the severity of the Great Depression. Bernanke's premise was that the series of increasingly severe banking crisis between 1930 and 1933 that led to the failure of nearly one-third of the nation's banks interfered with the ability of banks to exploit their information-gathering advantage and effectively intermediate. Information on borrowers was lost when banks failed; the cost to remaining banks of replicating this information was exorbitant. As the real costs of intermediation increased, small businesses experienced a credit squeeze. And the effects of this credit squeeze on aggregate demand were such 
that the recession of $1929 / 30$ was transformed into a protracted Great Depression. Bernanke's empirical analysis explains the depth of the downturn, but it is in his narrative history that he connects the depression's persistence to the loss of bankborrower relationships.

Calomiris and Mason (2003) extend Bernanke's analysis and find that a one standard deviation in loan supply during the depression led to a $7 \%$ decrease in state income between 1930 and 1933. Also consistent with the Bernanke hypothesis, Bodenhorn (2003) provides a micro-study of bank-borrower relationships during and after the panic of 1857 and finds that one bank's total lending declined by nearly $80 \%$ and average loan size declined by $25 \%$ in the year following the panic. The least creditworthy borrowers were cut off, but having maintained a relationship with the bank for an additional two years (one standard deviation) increased the probability of renegotiating an existing loan increased between 56 to $90 \%$. The evidence suggests that bank loans are a special, information-intensive form of finance and the specialness of bank-borrower relationship becomes manifest during a recession or credit squeeze.

Calomiris et al (1986) investigate the effects of the 1980s farm crisis on bank failures and how those failures further exacerbated the farm crisis. Because farm lending tends to be highly information intensive and highly localized, a bank failure is likely to have adverse effects on borrowers. Using an instrumental variables approach, they identify a short-run decline of about 1\% of real farm output following a bank failure. They suggest that the short-term effect may have longer-term consequences, but they do not test for them.

Gilbert and Kochin (1989) consider the effect of bank closings, as opposed to bank mergers, because closings are likely to have more substantial negative effects on growth because idiosyncratic information about borrowers is more likely to be lost following a closing. Like Calomiris et al (1986) they identify a short-term negative effect of local bank failures on local retail sales and employment and it is not clear that the negative effect persists in the longer term, though there is cross-country evidence that it does in developing economies (Boyd et al 2004).

Ramirez (2009; 2011) considers the bank failure-economic decline connection from a decidedly long-term perspective. Ramirez (2009) notes that establishing the finance-growth link through bank failures requires depends on meeting two 
requirements: enough time must elapse to establish a long-run effect; and, critically, government cannot institute policies designed to mitigate the downturn in the interim. One episode that satisfies both criteria is the period following the panic of 1893. Using OLS procedures, Ramirez finds that increased bank failures between 1893 and 1896 are associated with reduced rates of growth between 1900 and 1930. He scours local newspaper accounts and finds that the crisis reduced the public's confidence in banks, so that depositors were slow to reestablish their banking relationships. The loss of confidence, writes Ramirez (2011, p. 271), "becomes institutionalized ... [and] the systematic loss in deposits leads to a long-lasting financial disintermediation and a permanent destruction of bank lending capacity, thereby [negatively] affecting economic growth."

Ramirez and Shively (2012) employ a VAR approach consider the same 1900 to 1929 period to investigate the connection between bank and business failures. They find that the relationship was strongest in states with compulsory deposit insurance, which they believe exacerbated moral hazard problems. Insured banks took on more risks than uninsured banks so that bank failures had larger and more persistent effects on business failures. In a related paper, Curry, Fissel and Ramiriez (2008) argue that a loss of confidence in banks measured by a state-wide downgrade in CAMEL ratings leads to lower long-run state-level growth rates. But they acknowledge that establishing a strong causal link is challenging because government intervened in banking markets in too many dimensions in the 1980s and 1900s to draw strong inferences.

Ashcraft (2005) provides one of the more ingenious studies in this vein. In the 1990s, regulators closed two otherwise healthy banks affiliated with troubled bank holding companies. Because the closing of these healthy banks involved no loss of wealth or liquidity to uninsured depositors or other creditors, the principal mechanism through which the closings would affect local economic activity is through the destruction of bank-borrower relationships. Aggregate lending in these two Texas communities declined by about $18 \%$; unused loan commitments declined by $23 \%$. Ashcraft then estimates that the closing of a healthy bank leads to a decline of about $2.25 \%$ in real county income in a two-year, post-closing period. The failure of an 
unhealthy bank, by way of comparison, leads to a reduction in real county income of $5.9 \%$ in the following three years and a decline of $8.1 \%$ in six years.

What can be learned about the effect of banks on real economic activity from bank failures? If banks fail because they provide poor intermediary services, the contraction in credit should not have much of an effect on the efficiency of capital allocation because remaining banks are unlikely to have followed the failing banks policies and been more efficient allocators of credit. Yet, as Bernanke (1983) discussed, closing a bank and liquidating its assets will have a more pronounced effect when economic activity is already depressed. Ashcraft (2005) uses this to make his case that the closing of a healthy bank is close to an ideal experiment in a test of whether and how long it takes a closed bank's loan customers to reestablish a relationship and receive credit from a new lender on similar terms.

\section{Savings banks, private banks, and investment banks}

Commercial banks, of course, were not the only formal financial intermediaries operating in the nineteenth and twentieth-century U.S. Several other intermediaries arose that filled financial niches left under-served by commercial banks. Although few now accept the contention that commercial banks short-term lending focus necessarily contributed relatively little to fixed capital formation and, by implication, development in the early stages of industrialization, it was the case that commercial banks did not encourage household saving by providing a repository for small depositors. Commercial banks eschewed small accounts, preferring to serve merchants, manufacturers, and governments that maintained relatively large accounts. To the extent that domestic investment depended on domestic savings, industrial development depended on the emergence of alternative financial institutions willing to serve small savers and capable of transforming household savings into larger pools of capital that could suit the purposes of investors and entrepreneurs. Commercial banks also left a void in markets for mortgages, corporate debt and equities, international finance, trust and other services. The history of finance is, in part, a history of intermediaries that specialized in these services and contributed to economic development. 


\subsection{Mutual savings banks}

Referring back to the economic historian's model of development in Section 3, they emphasize the twin services of mobilizing savings and allocating capital among competing projects as the principal mechanisms through which finance influences growth. Increases in aggregate savings are a key element of growth because they provide for capital formation. Davis and Gallman (1978) estimate a 12\% savings rate in 1840 that increased to $20 \%$ in 1900 . This higher saving rate resulted from decisions made at the microeconomic level of the individual and household, and had macroeconomic implications (Alter et al 1994). The principal focus of the nation's early mutual savings banks was on increasing savings by the working class, so that they provide a link between micro- and macroeconomic activity.

Through the first two centuries of British North American and the US history (ca. 1600 -1800), a great deal, perhaps a majority, of household savings took the form of investments in and improvements to land. Early Americans saved by clearing and improving farm land in their youth that could be either sold or passed on to children who would support them in the old age. Savings banks appeared where and when they did - in the Northeast in the first half of the nineteenth-century - as an increasing number of citizens were moving into cities and laboring for money wages. It was a challenge for working-class, urban citizens to engage in long-term savings through land improvements, so they turned to cash savings to tide them through unemployment spells, to accumulate for consumer durable purchases, to provide for old age, and to make bequests. In making it easier for working-class households to save, savings banks encouraged the domestic savings that financed growth.

The earliest savings banks were viewed primarily as benevolent or philanthropic institutions designed by leading citizens in the nation's largest cities to reduce working-class poverty. The charter of New York City's first mutual savings banks stated that it was granted for "the laudable purpose of encouraging the community habits of industry and economy ... to ameliorate the condition of the poor" (Welfling 1968, p.v), which Wadhwani (2002) argues is an important function of

a liberal state. Over the course of the century, their purpose evolved from a self-help 
program for the poor, to a repository for savings for urban laboring classes, to a safe place for the deposit of substantial sums accumulated by an emergent middle class of shopkeepers, artisans and professionals who lacked the information to invest it on their own (Payne and Davis 1956; Olmstead 1976; Welfling 1968; Wadhwani 2002).

Qualitative evidence suggests that the responsiveness of savings to financial innovations that increased the convenience and the net yield and decreased the risk to savings. Davis and Gallman (2001, p.48) contend that responsiveness was likely to have been greater in the early stages of economic development when so few alternatives were available. The quantitative evidence also points to that conclusion. Table 1 reveals that between 1820 and 1860 the number of banks increased 28-fold and the number of open accounts 87-fold. Between the Civil War and the Great Depression, the number of banks doubled and the number of accounts increased 17fold. Olmstead (1976) reports that the number of savings bank deposit accounts in New York City in 1860 equaled one-fourth of the city's population. Using as a numerator the population of the northeastern US, which is the region in which most mutual savings banks were located, the data in Table 1 implies $0.1 \%$ of all individuals had an account in 1820. In 1860 it was more than $6 \%$ and more than $20 \%$ in 1900 . In the northeastern US, at least, savings banks drew an ever-larger fraction of the population into the ranks of savers. They also increased savings per person (Benston 1972). As late as 1960 metropolitan areas with savings banks had higher per capita savings rates relative to cities without such banks, after controlling for the number of commercial bank offices and other intermediaries. The increase in household savings at savings banks did not come at the expense of savings held in other institutions; it represented an increase in "the joint realization of a greater part of the savings potential of an area" (Schweiger and McGee 1961, p.50). 


\begin{tabular}{|c|c|c|c|c|c|}
\hline \multicolumn{6}{|c|}{ Table 1} \\
\hline \multicolumn{6}{|c|}{ Statistics of mutual savings banks in the US, $1820-1864$} \\
\hline Year & $\begin{array}{l}\text { Number } \\
\text { of Banks }\end{array}$ & $\begin{array}{c}\text { Total } \\
\text { Deposits } \\
\text { (\$ millions) }\end{array}$ & $\begin{array}{l}\text { Number } \\
\text { of accounts } \\
\text { (thousands) }\end{array}$ & $\begin{array}{c}\text { Average } \\
\text { deposit } \\
\text { (current \$) }\end{array}$ & $\begin{array}{l}\text { Average } \\
\text { deposit } \\
(1964 \$)\end{array}$ \\
\hline 1820 & 10 & 1 & 8 & 132 & 357 \\
\hline 1830 & 36 & 2 & 16 & 150 & 517 \\
\hline 1840 & 61 & 14 & 78 & 179 & 663 \\
\hline 1850 & 108 & 43 & 251 & 173 & 721 \\
\hline 1860 & 278 & 149 & 693 & 215 & 827 \\
\hline 1870 & 517 & 549 & 1,630 & 337 & 822 \\
\hline 1880 & 629 & 819 & 2,336 & 351 & 1,097 \\
\hline 1890 & 637 & 1,336 & 3,765 & 325 & 1,161 \\
\hline 1900 & 652 & 2,134 & 5,370 & 397 & 1,527 \\
\hline 1910 & 638 & 3,361 & 7,480 & 449 & 1,497 \\
\hline 1920 & 620 & 5,172 & 9,445 & 547 & 842 \\
\hline 1930 & 606 & 9,191 & 11,895 & 772 & 1,430 \\
\hline 1940 & 540 & 10,618 & 15,624 & 680 & 1,511 \\
\hline 1950 & 529 & 20,025 & 19,264 & 1,040 & 1,333 \\
\hline 1960 & 515 & 36,343 & 22,493 & 1,616 & 1,683 \\
\hline 1964 & 506 & 48,849 & 22,231 & 2,197 & 2,197 \\
\hline \multicolumn{6}{|c|}{$\begin{array}{l}\text { Source: Welfling ( 1968, p.15); "How Much is That" calculator, available } \\
\text { at EH.net }\end{array}$} \\
\hline
\end{tabular}

In real terms, the average account increased more than six-fold, recognizing the inherent imprecision of inflation adjustments across such vast stretches of time, which suggests that Schweiger and McGee's finding for the mid-twentieth century applies to the earliest days of the mutual savings bank. They pulled more savers into the market and encouraged each to save more. This accords with what is known about domestic savings rates. A study of the Philadelphia Saving Fund Society for 1850, for instance, estimates a savings rate of 10 to $12 \%$ per year for laborers and artisans, which is consistent with the savings rate estimates provided by Davis and Gallman (2001) and others (Alter et al 1994). They also report that savings accounts at the 
Philadelphia Saving Fun opened in 1850 that remained open for two to five years totaled about one-half of a male laborer's gross annual income, which approximately the same (53\%) as the 1960 ratio of the average value of a deposit to per capita gross domestic product. "Perhaps because of specialization," writes Benston (1972, p.170), "savings banks became widely accepted by consumers as 'the place to save."

The success of mutual savings banks in encouraging saving among working and middle-class households led others to try to replicate their results. Sereno Miller, opened the first school savings bank in Beloit, Wisconsin in 1876. School savings banks aimed to teach youth the value saving (Zook 1920). By 1892 there were 27,430 depositors in school savings banks in 12 states. In 1915 there were programs in nearly 2,000 schools in 280 cities that held $\$ 1.8$ million in deposits, or about $\$ 50$ million in real 2015 dollars. Although it had a checkered career, the Freedmen's Savings Bank was established in 1865 to provide freed slaves with mechanism for independence and self-improvement (Miller 1980).

In general, savings banks provide the same economic functions as other intermediaries; they provide a relatively liquid, short- to medium-term earning asset to savers and invest in relatively illiquid, long-term debt, mainly government and corporate bonds and residential mortgages. Like other intermediaries they are not "mere middlemen" (Welfling 1968, p.161). They hold assets that savers would otherwise be unwilling to hold and their liabilities are more liquid than those that individual borrowers would be able to provide directly.

Schweiger and McGee (1961) contend that it is of no small import that local savings banks increase local savings rates because higher per capita savings rates makes more funds available to local lenders who presumably possess informational advantages over more distant lenders. Such advantages should translate into a more efficient allocation of capital because local lenders are better positioned to judge the merits of the applicant and because local lenders are likely to give greater weight to projects likely to advance the long-run interests of the community. And to the extent that capital is not perfectly mobile across space, as short-term capital was not in the postebllum era, any institution that simultaneously increases savings rates and improves the allocation of capital offers obvious advantages for local development. In their assessment of Baltimore's early savings banks, however, Payne and Davis (1956) 
and Davis and Payne (1958) offer critical assessments of home bias in savings bank investments, arguing that a home bias limited the banks' usefulness as intermediaries. How one interprets local lending depends, in part, on how one interprets the difference between the average and the marginal loan.

Home bias was as much a consequence of regulations and restrictions on investments as managerial myopia. Because mutual savings banks were envisioned as semi-philanthropic institutions that would provide a safe repository for household savings, bank managers invested conservatively. In New York, for instance, early savings banks were restricted to New York State and New York City municipal debt. The rapid growth in savings deposits pushed bankers into lobbying for a wider choice of investment options, so that by the Civil War they could invest in out-of-state bonds, a wide range of municipals, residential mortgages, some of which might be out of state, and call loans secured by corporate stock and government debt (Olmstead 1974b; 1976).

But the issues are whether savings bank investments promoted economic development and, if so, how. Olmstead (1976) argues that New York City's savings banks were instrumental to the construction of the Erie Canal. Despite Sylla's (1998) contention that an active secondary securities market arose early in the US, the market was thin and securties still illiquid in 1819 when the canal commissioners started marketing Erie bonds. For more than a decade the Bank for Savings in New York was the single largest holder of Erie Canal debt, at times owning as much as $30 \%$ of the total outstanding volume. Not only did the Bank for Savings support the construction of the single most profitable infrastructure project of the antebellum era, which created far-reaching economic spillovers, it made a market for canal debt, which encouraged wide private ownership of that debt (Livingood 1947; Bernstein 2005; Sokoloff 1988).

Mutual savings banks' direct financing of industry was modest by comparison to the finance it provided transportation, first canals and then railroads, through bond ownership. Nevertheless, detailed micro-level studies reveal support for manufacturing and industry. In their study of the Savings Bank of Baltimore, Payne and Davis (1956) find that while "industrial" loans accounted for less than $10 \%$ of its lending, the range of enterprises it supported included iron founders, smelters, chemical works, 
breweries, sugar refiners, and rail manufacturers, among others. The range of these investments were the more remarkable because Baltimore was not yet an industrial city. Beveridge's (1985) study of the Cheshire Provident Institution for Savings founded in 1832 in Keene, New Hampshire uncovered loans to textile mills and myriad other industrial firms. About two-thirds of its loans were to manufacturers compared to $21 \%$ to merchants. More telling perhaps is Beveridge's (1985, p. 398) observation that the Cheshire Provident "development [start-up] capital needed first for the textile industry, then for saw milling and woodworking, then for leather and shoes, and, finally, for machine tools." As the local economy was modernizing, the local supplier of capital responded, not just passively by extending loans but actively by providing some start-up capital to local entrepeneurs.

Figure 3 reports the fraction of each of the principal securities held by mutual savings bank assets in the first two-thirds of the twentieth century. The growing volume of total assets held by the banks raised investment concerns beyond the regulatory restrictions placed on them. Welfling (1968) reports that liquidity concerns became increasingly important. Bankers learned that small business loans and corporate shares were relatively illiquid in recessions. Residential mortgages tended to be safe but illiquid, too, so some banks increasingly turned to commercial property mortgages. Government securities were the most liquid, but offered the lowest returns. Movements in asset classes seen in Figure 3 reveal that, outside the Second World War when US securities holding increased markedly, mutual savings banks held about 40 to $60 \%$ of their assets in mortgages, 10 to $20 \%$ in corporate securities, $5 \%$ or less in cash, and most of the remainder in local, state, and federal debt. As late as the 1970s savings banks continued to specialize in small to medium individual savings accounts on the liability side, and mortgages and private and public bonds on the asset side. Benston (1972, p.138), however, made a case for a wider range of investments because in many small communities a local savings bank was likely to be a business's "best source of credit." 
Figure 3

Source: Carter et al (2006), series Cj362-374.

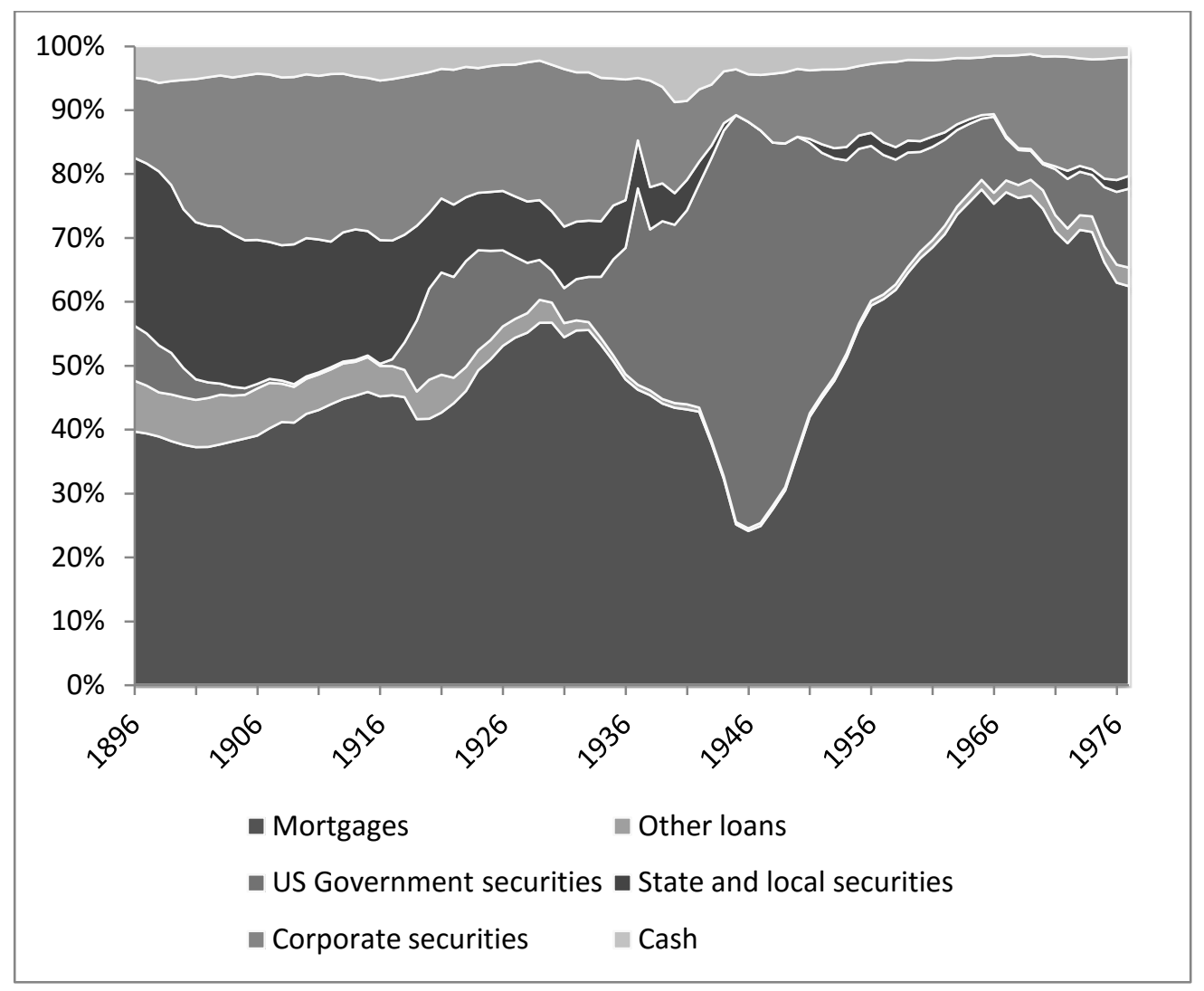

A recent reinterpretation of the nineteenth-century savings banks offers a positive assessment (Wadhwani 2004). As first movers in the effort to mobilize the savings of working and middle-class households, savings banks increased the returns to and reduced the costs and risks of participation in the formal financial system. They demonstrated the viability of serving small savers, and the profitability of the savings bank model drew commercial banks, trust companies and life insurance companies into the market for household savings. The model became sufficiently attractive, in fact, that savings banks eventually abandoned their original task of serving the poor and working classes and encouraged, even competed for, large deposits from relatively wealthy savers (Olmstead 1975). Given the absence of alternative vehicles, a substantial fraction of the savings accumulated by savings banks represented a net 
addition to the stock of savings. Despite restrictions on savings bank investments, savings banks directed not insubstantial volumes of funds into government-directed social overhead capital, short- and long-term business lending, and residential mortgage markets. All contributed to long-run growth.

Those who supported the development of institutions to promote saving among the working classes, such as Emerson Keyes (1878), a New York Savings Bank Commissioner, tended to focus on the microeconomic benefits of savings on households. Saving afforded working class households the opportunity to tide themselves over through unemployment spells or illnesses and the opportunity to buy their own home. At the macro-level their concern was in less how an increase in savings might stimulate economic development, but in how a mindset of industriousness and self-help would reduce idleness, vagabondage and crime. Small savings accounts increased thus increased aggregate output by increasing the quality and quantity of labor supplied to the market and by freeing up resources toward productive activity that had previously been used to avoid destructive criminal activity. All of these effects are of no small consequence and, despite some research into unemployment spells and the constancy of employment in the nineteenth century, economic history would be well served to better understand the extent to which idleness and crime were reduced and whether an expanding financial sector can be credited with any part of the amelioration of urban conditions and their ancillary growth effects (Atack et al 2002; Averett et al 2003).

\subsection{Investment and private banks}

“...a private banker, doing an investment business, bought securities for others, kept deposits..., bought and sold securities for the account of [his] firm, transferred credits, floated securities either singly or as a member of a syndicate, and acted as a financial agent for corporations." (Gras 1936, p.xi)

Gras's depiction of an investment bank is consistent with the modern interpretation of a financial intermediary's value added: they assess the potential profitability of alternative projects, allocate capital between and among those projects,

monitor those that receive funding, and offer advice and ancillary services before and 
after each round of financing. Although the functions of an investment banker do not differ in the abstract from that of a commercial or savings bank, they were organized on different bases and provided different services. Organized mostly as partnerships rather than corporations, investment banks mostly arranged long-term funding for corporate, fixed capital investment, rather than short-term working capital or longterm mortgage finance. Although private and investment banks have not received as much attention from economic historians as commercial and savings banks - mostly because they left a smaller evidentiary footprint in the historical record -- there are enough quality studies to understand how they conducted their business and how they influenced economic development (Sylla 1976).

How firms arrived at investment banking was almost as varied as the number of firms in the industry. Stephen Girard, of Philadelphia, is considered the first of America's investment bankers. In consultation with Alexander Baring of London, Girard established a combination commercial-private-investment bank, partly to capture some of the business made available by the closing of the Bank of the United States in 1811. Baring considered a commercial-private-investment model more suited to certain types of business, especially foreign exchange, because such business required quick decisions and confidentiality, features unlikely to exist in banks with a dozen or more directors privy to every major decision (Larson 1936; Adams 1978). Girard accepted deposits, made short-term commercial loans, and bought and sold bills of exchange. His entry into investment banking occurred during the War of 1812. When the US treasury was unable to place its $\$ 16$ million bond offering to finance the war, a syndicate of Stephen Girard, John Jay Astor and David Parrish, US representative of Baring Brothers, bought $\$ 10$ million worth of bonds then resold them to business and family connections. When subscriptions for the stock offering of the Second Bank of the United States lagged in 1816, Girard alone purchased the last $\$ 3$ million in shares, most of which he later resold (Redlich 1968; Adams 1978).

Other early private/investment banks included S. \& M. Allen and Yates \& McIntyre, which built up national organizations with branches that served as lottery ticket sales offices. In the early nineteenth century, lotteries were used to raise money for such infrastructure projects as roads, canals, river clearings, schools and even jails. By one estimate lottery ticket sales exceeded $\$ 53$ million in 1832 alone (Carosso 1970). 
Lottery sales tapped into small savings across socioeconomic classes; Denmark Vesey, who instigated a slave rebellion in Charleston, South Carolina in 1822, purchased his freedom after winning a lottery.

Anthony Drexel came to investment banking by way of the domestic exchange and banknote brokerage business (Rottenberg 2006). Junius Morgan came to it in 1854 by way of the international wholesale dry goods business. The joining of these two houses into Drexel, Morgan \& Co. eventually transformed itself into the late nineteenth-century financial powerhouse, J. P. Morgan \& Co. Of the private banks established prior to the Civil War, Winslow, Lanier \& Co. came the closest to a modern investment bank. Its principal business was marketing railroad securities to English and European banking houses. It was among the first to sell securities through sealed-bid auctions and to install members of the firm on the boards of directors of the roads whose securities they placed. In doing so, Winslow, Lanier "gave advice on financial matters, presided over reorganizations, and proposed policies designed to protect the value of the securities they had sponsored" (Carosso 1970, p.12).

Although the needs of underwriting and marketing railroad bonds led to the rise (and fall) of major investment banks in the late nineteenth century, these banks eschewed the underwriting and distribution of common shares of rails and industrials (Larson 1936). This left an opening for firms, like Goldman, Sachs \& Co. and Lehman Brothers, who believed there was a large market for securities of manufacturing and retail companies and provided equity underwriting services for firms like Sears, Roebuck \& Co. Smaller private/investment banks, such as Branch \& Company of Richmond, Virginia, provided similar services to local and regional firms (Bodenhorn 1997). Trust companies, too, emerged in the late nineteenth century in response to widening and deepening markets for industrial securities and provided a variety of underwriting and investment services (Neal 1971).

A number of studies offer some evidence of a positive link between investment banking and economic development by way of the information revealing, monitoring and disciplining mechanism highlighted elsewhere in the finance-growth literature (Levine 1997). Investors saw investment bankers' participation in underwriting syndicates and their subsequent placement of bankers on corporate boards of directors as banker's "stamp of approval." Bankers demanded seats on 
board not because they wanted to control the corporations or to lock the corporation into using the bank for future securities issues or even ensure their place in the socalled money trust; rather, they demanded a seat on corporate boards to keep an eye on the corporations' actions, to ensure that the investment banker's recommendation of the firms' securities was warranted, and to protect their own reputation as originators and retailers of profitable securities (Carosso 1970).

De Long (1991) collected share price and other financial data for 20 firms with a Morgan man on the board and 61 comparably sized firms without. Having a Morgan man on the board raised the firm's common stock value by about 30\%. The increase in share price resulted from the Morgan firm's higher profitability, not a higher share price for a given profitability. Ramirez and De Long (1995) consider the effects of having a banker on a corporate board before and after New Deal reforms. They find a strong positive effect of having a banker on the board before and small negative effect after. They tentatively conclude that the New Deal reforms eliminated the monitoring and disciplining effect of direct bank supervision of corporate management, butthey do not identify any particular reform that would have generated this effect (Wigmore 1995). Frydman and Hilt (2014) utilize the plausible exogeneity of the Clayton's Act prohibition against investment bankers serving on railroad boards, but not industrial firms', boards and construct a panel dataset to investigate De Long's monitoring hypothesis. They find that railroads with stronger banking relationships prior to 1914 experienced larger declines in investment rates, valuations, and leverage after the prohibition finally went into effect in 1921. No comparable effects are found for industrial firms, which were not subject to the prohibition. Like De Long, Frydman and Hilt (2014) interpret their findings to imply that investment bankers served as delegated monitors, which increased aggregate investment and the efficiency with which it was invested.

One concern with these results is the small sample sizes in all three studies (50 to 70 firms) and the possibility their results may be driven by one or more outliers. De Long discounts this possibility; Frydman and Hilt trim their sample by two percent. Another is that cross-section regressions cannot tease out a causal interpretation, a criticism that may not apply to Frydman and Hilt. A third is that the analyses do not and cannot disentangle whether the investment banker (the "Morgan man" in De 
Long's terminology) on the board was actively involved in hiring, monitoring, and disciplining upper management or whether their presence was purely nominal and served more to increase the prestige of the banker than the corporation on whose board he served (Wigmore 1995), though Ramirez (1999) provides evidence pointing toward banker influence. A fourth is that the argument that investment banks behave in the present so as to protect their future reputation, which, though plausible, hangs on a theoretically slender reed.

Fifth, and this is fundamental to interpreting the investment bankers' contribution to growth in the Gilded Age, is whether a corporation's alliance with an investment banker increased efficiency or simply helped secure market structures somewhat closer to monopoly. While the evidence is consistent with the delegated monitoring view of financial intermediaries, it is not inconsistent with the possibility that Morgan-man firms realized market power by way of their Morgan connection. Sabel (1991) argues that the large investment banks' reputations were not that of behaving as a delegated monitor, as some notable refinancing fiascoes make clear. Instead, bankers were known for their ability to reorganize markets and industrial sectors in ways that made existing companies more profitable, even after issuing large amounts of debt in the restructuring process. Markets punished excessive self-dealing by bankers, but having a banker on a board also created conflicts of interest: was a Morgan man's principal responsibility to protect the investment bank, or was it, as they claimed, to protect retail investors. If it is the case, as Sabel (1991) contends, that the bankers' value added originated from their ability to construct companies, warrant them against failure, and then stand behind the warranty regardless of postrestructuring efficiency, then conflicts of interest imposed a tax on retail investors and the implicit warranties, in certain circumstances, misallocated resources and may have acted more as a drag on than an accelerant of economic development. The decline in the value of post-Clayton Act railroads then may have been due more to the increased difficulties of Morgan, Kuhn, Loeb and others to further consolidate or coordinate competing lines than to their diminished ability to monitor.

One of the most-studied New Deal financial regulations was the Glass-Steagall Act, which created federal deposit insurance and effectively separated commercial and investment banking. White (1986), Benston (1990), Kroszner and Rajan (1994) and 
Puri (1994) argue that the forced separation "fixed" problems - conflicts of interest, misrepresentation, excessive risk taking -- that did not exist. One result of the separation of commercial and investment banking was that it made it more difficult for nonfinancial firms to issue securities and raise capital (Ramirez and De Long 1995). Ramirez (1999) finds that before Glass-Steagall corporate investment spending was sensitive to internal liquidity and cash flow only for firms with weak bank affiliations; after Glass-Steagall investment spending was sensitive to liquidity for all firms. In forcing banks to divest their investment banking affiliates, Glass-Steagall increased the costs of capital and forced nonfinancial firms to rely more on internally generated funds to finance investment.

Neal and White (2012) suggest that the effects were more widely dispersed than the NYSE-listed firms analyzed by Ramirez (1999). In the late 1920s, nearly 45\% of bond originations were handled by the securities affiliates of commercial banks. Much of the affiliates' business was done on behalf of small- and medium-size firms, which were the traditional clients of commercial banks. Moreover, many of these small- and medium-size firms were young and exploiting innovative technologies and the rate of growth of the flow of outside funds to these firms slowed significantly after 1933. Two long-run consequences of the separation of commercial and investment banking was that the lead bank in an underwriting syndicate became less important in providing a "seal of approval" to a securities issue, and the newly deposit-constrained investment banks focused more on the issues of large, established firms, which may explain why research and development shifted away from small toward large corporations beginning in the 1930s (Flandreau 2001; Lamoreaux et al 2011; Field 2011). More work needs to be done to fully understand the growth-inhibiting effects, if any, of Glass-Steagall and other New Deal reforms, but the research to date suggests that the price of mid-century financial stability was a vibrant, innovative investment banking sector.

\section{Concluding comments}


Economic and financial historians argue that any informed reading of US financial history points to at least one financial revolution (1790s-1830s), and two periods of genuine financial innovation, one in the late nineteenth and early twentieth century (commonly labeled the era of "finance capitalism") and one in the late twentieth and early twenty-first century, in which the types, volume, even the very nature of financial intermediation fundamentally changed (Navin and Sears 1955). Between 1897 and 1917, the share of bank assets to gross domestic product rose from $57.5 \%$ to $75.0 \%$; between 1980 and 2008 , the ratio rose by a strikingly similar $51.2 \%$ to $74.8 \%$, and the latter understates the true rise because it does not account for the activities of so-called shadow banks and the off-balance sheet activities of commercial banks (Neal 1971; Federal Reserve Bank of St. Louis 2016). Historians have yet to place enough distance between themselves and recent events to assess the long-term consequences of the resurgence of finance capitalism between 1980 and 2008, but the evidence is consistent with an interpretation that financial innovation tends to lead periods of industrial growth and technological change. One source of doubt concerning the finance-growth connection, surely, is that ends of financial innovation are often punctuated by financial panics. The political drama and the short-run economic pains consequent to panics lead even informed observers, like Paul Volker who doubts the social value of every recent innovation except the automated teller machine, to question whether the benefits of financial innovation are worth the price of panic (Economist 2012). Yet panics themselves sometimes provide for a period of cleansing, reflection, political coalition building and regulatory change that lay the foundation for the next wave of beneficial financial innovation (Hoffman et al 2009).

For a period of financial innovation to promote long-run development, the activities of financial intermediaries, capital markets, and regulators must be complementary, as Sylla's (1998) analysis of the Federalist financial revolution makes clear. Federalist policy encouraged trust in intermediaries and markets, and markets facilitated the expansion of intermediaries. Events do not always unfold so seamlessly, however. Innovations tend to occur selectively rather than systemically, which disrupts any complementarities and often result in financial crises (Neal and White 2012). Adaptation in the other sectors lags, which challenges their traditional practices and operations. The lags can be substantial in the governmental sector because regulatory 
adaptation often demands the construction of a political coalition capable of generating a consensus for new regulations (Hoffman et al 2009).

The history of US finance is marked by brief periods of financial and regulatory innovation - free banking, national banking, securitization, and so on - for which their consequences in regard to long-run development take decades to play out. Regulators purposely channeled some of the earliest bank's activities into the provision of growth-enhancing social overhead capital, including roads, bridges, canals, railroads, waterworks and street lights. In the National Banking Era, the federal government tightened the reins on commercial banks, partly in order to channel their resources toward financing an expensive Civil War. The restrictions placed on commercial banks by the Civil War-era acts, however, opened the door to state banks, savings banks, investment banks, private banks, mortgage companies, and trust companies to provide financial services commercial banks could not. One lesson from history is that finance finds a way. Prohibiting one type of intermediary from engaging in one or more types of growth-enhancing activity promotes the development and entry of new types. Whether this is an optimal path is arguable (Calomiris 1995), but it is the path followed by the US for the past two centuries, two centuries of remarkable economic development.

\section{References}

Adams, Donald R., Jr. 1975. "The role of banks in the economic development of the Old Northwest." In Essays in Nineteenth Century Economic History: The Old Northwest, pp. 208- 245. Edited by David C. Klingaman and Richard K. Vetter. Athens: Ohio University Press.

Alter, George, Claudia Goldin and Elyce Rotella. 1994. "The savings of ordinary Americans: The Philadelphia Saving Fund Society in the mid-nineteenth century." Journal of Economic History 54(4): 735-767.

Ashcraft, Adam B. 2005. "Are banks really special? Evidence from the FDIC-induced failure of healthy banks." American Economic Review 95(5): 1712-1730. 
Atack, Jeremy, Fred Bateman, and Robert A. Margo. 2002. "Part-year operation in nineteenth-century American manufacturing: Evidence from the 1870 and 1880 censuses." Journal of Economic History 62(3): 792-809.

Atack, Jeremy, Matthew Jaremski, and Peter L. Rousseau. 2014. "American banking and the transportation revolution before the Civil War.” Journal of Economic History 74(4): 943986.

Atack, Jeremy, Matthew Jaremski, and Peter L. Rousseau. 2015. "Did railroads make antebellum US banks more sound? In Enterprising America: Businesses, Banks, and Credit Markets in Historical Perspective, pp. 149-178. Edited by William Collins and Robert A. Margo. Chicago: University of Chicago Press.

Averett, Susan, Howard Bodenhorn, and Justus Saisiunas. 2003. "Unemployment risk and compensating differentials in late-nineteenth-century New Jersey manufacturing." Economic Inquiry 43(4): 734-749.

Beck, Thorsten and Asli Demirguc-Kunt. 2006. "Small and medium-size enterprises: Access to finance as a growth constraint." Journal of Banking \& Finance 30( ): 2931-2943.

Bencivenga, Valerie and Bruce Smith. 1991. "Financial intermediation and endogenous growth." Review of Economic Studies 58(x): 195-209.

Benston, George J. 197x. "Savings banking and the public interest." Journal of Money, Credit, and Banking 4(1): 133-226.

Benston, George J. 1990. The Separation of Commercial and Investment Banking: The Glass-Steagall Act Revisited and Reconsidered. New York: Oxford University Press.

Bernanke, Ben S. 1983. "Nonmonetary effects of the financial crisis in the propagation of the Great Depression.” American Economic Review 73(3): 257-276.

Bernstein, Peter L. 2005. Wedding of the Waters: The Erie Canal and the Making of a Great Nation. New York: W. W. Norton \& Company.

Beveridge, Andrew A. 1985. "Local lending practice: Borrowers in a small northeastern industrial city, 1832-1915." Journal of Economic History 45(2): 393-403.

Black, Sandra and Philip Strahan. 2002. "Entrepreneurship and bank credit availability." Journal of Finance 57(6 ): 2807-2833.

Bodenhorn, Howard. 1992. "Capital mobility and financial integration in antebellum America." Journal of Economic History 52(3): 585-610. 
Bodenhorn, Howard. 1995. "A more perfect union: Regional interest rates in the United States, 1880-1960." In Anglo-American Financial Systems: Institutions and Markets in the Twentieth Century, pp. 415-454. Edited by Michael D. Bordo and Richard Sylla. Burr Ridge, Ill.: Irwin Professional Publishing.

Bodenhorn, Howard. 1997. "Private banking in antebellum Virginia: Thomas Branch \& Sons of Petersburg." Business History Review 71(4): 513-542.

Bodenhorn, Howard. 1998. "Free banking and financial entrepreneurship in nineteenthcentury New York: The Black River Bank of Watertown.” Business and Economic History 27(1): 102-114.

Bodenhorn, Howard. 1999. "An engine of growth: Real bills and Schumpeterian banking in antebellum New York." Explorations in Economic History 36(3): 278-302.

Bodenhorn, Howard. 2000. A History of Banking in Antebellum America: Financial Markets and Economic Development in an Era of Nation-Building. New York: Cambridge University Press.

Bodenhorn, Howard. 2003. "Short-term loans and long-term relationships: Relationship lending in early America.” Journal of Money, Credit, and Banking 34(4): 485-505.

Bodenhorn, Howard. 2007. "Usury ceilings and bank lending behavior: Evidence from nineteenth-century New York.” Explorations in Economic History 44(2): 179-202.

Bodenhorn, Howard. 2011. "State and federal commercial banking policy in the Federalist Era and beyond." In Founding Choices: American Economic Policy in the 1790s, pp. 151176. Edited by Douglas A. Irwin and Richard Sylla. Chicago: University of Chicago Press.

Bodenhorn, Howard and David Cuberes. 2010. "Financial development and city growth: Evidence from northeastern American cities, 1790-1870." National Bureau of Economic Research working paper 15997.

Bodenhorn, Howard and David Cuberes. 2015. "Finance and urbanization in early nineteenth-century New York.” Clemson University working paper.

Bodenhorn, Howard and Hugh Rockoff. 1992. "Regional interest rates in antebellum America." In Strategic Factors in Nineteenth Century American Economic History: A Volume to Honor Robert W. Fogel, pp. 158-187. Chicago: University of Chicago Press.

Bogue, Alan. 1969. Money at Interest: The Farm Mortgage and the Middle Border. Lincoln: University of Nebraska Press. 
Bordo, Michael D. and Peter L. Rousseau. 2006. "Legal-political factors and the historical evolution of the finance-growth link." European Review of Economic History 10( ): 421-444.

Boyd, John H and Bruce D. Smith. 1996. "The co-evolution of the real and financial sectors in the growth process." World Bank Economic Review 10(2): 371-396.

Boyd, John H and Bruce D. Smith. 1998. "The evolution of debt and equity markets in economic development." Economic Theory 12(3): 519-560.

Boyd, John, Sungkyu Kwak, and Bruce Smith. 20xx. "The real output losses associated with modern banking crises." Journal of Money, Credit, and Banking 37(6): 977-999.

Brandeis, Louis D. 1933. Other People's Money and How the Bankers Use It. Washington: National Home Library Foundation.

Breckenridge, Roeliff Morton. 1898. "Discount rates in the United States." Political Science Quarterly 13: 119-142.

Bruchey, Stuart. 1965. The Roots of American Economic Growth, 1607-1861: An Essay in Social Causation. New York: Harper \& Row, Publishers.

Brunt, Liam and Edmund Cannon. 2012. "How does finance generate growth? Evidence from the first industrial revolution.” Working paper, NHH-Bergen.

Calomiris, Charles W. 1995. "The costs of rejecting universal banking: American finance in the German mirror, 1870-1914. In Coordination and Information: Historical Perspectives on the Organization of Enterprise, pp. 257-315. Edited by Naomi R. Lamoreaux and Daniel M. G. Raff. Chicago: University of Chicago Press.

Calomiris, Charles W., R. Glenn Hubbard, and James H. Stock. 1986. "The farm debt crisis and public policy." Brookings Papers on Economic Activity 1986(2): 441-479.

Calomiris, Charles W. and Carlos D. Ramirez. 1996. "Financing the American corporation: The changing menu of financial relationships." In The Corporation in Modern Society: $A$ Second Look, pp. Edited by Carl Kaysen. New York: Oxford University Press.

Cameron, Rondo and Hugh T. Patrick. 1967.'Introduction." In Banking in the Early Stages of Industrialization: A Study in Comparative Economic History., pp. 1-14. Edited by Rondo Cameron et al. New York: Oxford University Press.

Cameron, Rondo (ed.). 1972. Banking and Economic Development. New York: Oxford University Press. 
Campen, James T. and Anne Mayhew. 1988. "The national banking system and southern economic growth: Evidence from one southern city, 1870-1900." Journal of Economic History 48(1): 127-137.

Carosso, V. 1970. Investment Banking in America. Cambridge, Mass.: Harvard University Press.

Carter, Susan B, et al. (eds.). 2006. Historical Statistics of the United States: Millennial Edition. New York: Cambridge University Press.

Chabot, Benjamin Remy. 2000. The integration of nineteenth-century stock exchanges. Ph. diss., Northwestern University.

Chandler, Alfred D., Jr. 1977. The Visible Hand: The Managerial Revolution in American Business. Cambridge: Harvard University Press.

Coase, Ronald. 1937. “The nature of the firm.” Economica 4(16): 386-405.

Cole, Rebel A., Fariborz Moshirian, and Qiongbing Wu. 2008. "Bank stock returns and economic growth.” Journal of Banking \& Finance 32( ): 995-1007.

Conrad, Alfred H. 1961. "Income growth and structural change." In American Economic History, pp. 26-64. Edited by Seymour E. Harris. New York: McGraw-Hill.

Cull, Robert, Lance E. Davis, Naomi R. Lamoreaux, and Jean-Laurent Rosenthal. 2006. "Historical financing of small- and medium-size enterprises." Journal of Finance \& Banking 30( ): 3017-3042.

Curry, Timothy J., Gary S. Fissel, and Carlos D. Ramírez. 2008. "The impact of bank supervision on loan growth." North American Journal of Economics and Finance 19(x): 113-134.

David, Paul A. 1967. "The growth of real product in the United States before 1840: New evidence, controlled conjectures." Journal of Economic History 27(2): 151-197.

Davis, Lance E. 1958. "Stock ownership in the early New England textile industry." Business History Review 32(2): 204-222.

Davis, Lance E. 1960. "The New England textile mills and the capital markets: A study of industrial borrowing, 1840-1860." Journal of Economic History 20(1): 1-30.

Davis, Lance E. 1963. "Capital immobilities and finance capitalism: A study of economic evolution in the United States 1820-1920." Explorations in Entrepreneurial History 1(1): 88-105.

Davis, Lance E. 1966. "The capital markets and industrial concentration: The US and UK, a comparative study." Economic History Review 19(2): 255-272. 
Davis, Lance E. 1971. "Capital mobility and economic growth." In The Reinterpretation of American Economic History, pp. 285-300. Edited by Robert William Fogel and Stanley L. Engerman. New York: Harper \& Row.

Davis, Lance E. and Robert Gallman. 1978. "Capital formation in the United States during the nineteenth century." In The Cambridge Economic History of Europe, vol. 7: The Industrial Economies: Capital, Labour, and Enterprise, part 2. Cambridge: Cambridge University Press.

Davis, Lance E. and Robert Gallman. 2001. Evolving Financial Markets and International Capital Flows: Britain, the Americas, and Australia, 1865-1914. New York: Cambridge University Press.

Davis, Lance E. and Peter Lester Payne. 1958. "From benevolence to business: The story of two savings banks.” Business History Review 32(4): 386-406.

De Gregario, Jose and Pablo Guidotti. 1995. "Financial development and economic growth." World Development 23(3): 433-448.

Dehejia, Rajeev and Adriana Lleras-Muney. 2007. "Financial development and pathways of growth: State branching and deposit insurance laws in the United States, 1900-1940.” Journal of Law and Economics 50(2): 239-272.

De Long, J. Bradford. 1991. “Did Morgan's men add value? An economist's perspective on finance capitalism." In Inside the Business Enterprise: Historical Perspectives on the Use of Information, pp. 205-236. Edited by Peter Temin. Chicago: University of Chicago Press.

Dexter, Seymour. 1891. "The Growth and Economic Value of Building and Loan Associations" Publications of the American Economic Association 6(1): 141-144.

Diamond, Douglas W. 1984. "Financial intermediation and delegated monitoring." Review of Economic Studies 51(3): 393-414.

Diamond, Douglas W. 1991. "Monitoring and reputation: The choice between bank loans and directly placed debt." Journal of Political Economy x(x): 689-721.

Easterlin, Richard. 1960. "Interregional differences in per capita income, population, and total income, 1840-1950." In Trends in the American Economy in the Nineteenth Century, pp. 73-140. Princeton: Princeton University Press.

Economist. 2012. "Why finance is good for us." The Economist (April 7). 
Eichengreen, Barry. 1984. "Mortgage interest rates in the populist era." American Economic Review 74(5): 955-1015.

Federal Reserve Bank of St. Louis. 2016. FRED Economic Data. Total Assets, All Commercial Banks. Available at https://fred.stlouisfed.org/series/TLAACBW027SBOG.

Field, Alexander J. 2011. A Great Leap Forward: 1930s Depression and U.S. Economic Growth. New Haven: Yale University Press.

Flandreau, Marc. 2011. "New deal financial acts and the business of foreign debt underwriting: Autopsy of a regime change.” CEPR-Norges Bank working paper.

Fohlin, Caroline. 2012. Mobilizing Money: How the World's Richest Nations Financed Industrial Growth. New York: Cambridge University Press.

Freyer, Tony A. 1976. "Negotiable instruments and the federal courts in antebellum American business.” Business History Review 50( ): 435-455.

Frydman, Carola and Eric Hilt. 2014. "Investment bankers as corporate monitors in the early $20^{\text {th }}$ century United States.” NBER working paper 20544.

Fulford, Scott. Forthcoming. "If financial development matters, then how? National banks in the United States, 1870-1900. Review of Economics and Statistics (forthcoming).

Gallatin, Albert. 1831. Considerations on the Currency and Banking System of the United States. Philadelphia: Carey \& Lea.

Gallman, Robert E. and Edward S. Howle. 1971. "Trends in the structure of the American economy since 1840." In The Reinterpretation of American Economic History, pp. 25-37. Edited By Robert William Fogel and Stanley L. Engerman. New York: Harper \& Row.

Gertler, Mark. 1988. "Financial structure and aggregate economic activity." Journal of Money, Credit, and Banking 20(3): 559-588.

Gilbert, R. Alton, and Lewis A. Kochin. 1989. "Local economic effects of bank failures." Journal of Financial Services Research 3(4): 333-345.

Goldin, Claudia. 2001. "The human capital century and American leadership: Virtues of the past." Journal of Economic History 61(2): 263-292.

Goldsmith, Raymond W. 1955. A Study of Saving in the United States. Princeton, N.J.: Princeton University Press. 
Goldsmith, Raymond W. 1958. Financial Intermediaries in the American Economy since 1900. Princeton, N.J.: Princeton University Press.

Goldsmith, Raymond W. 1968. Financial Institutions. New York: Random House.

Goldsmith, Raymond W. 1969. Financial Structure and Development. New Haven: Yale University Press.

Golembe, Carter. 1952. State Banks and the Economic Development of the West. Ph.D. dissertation, Columbia University.

Gras, N. S. B. 1936. "Editor's introduction.” In Jay Cooke, Private Banker, pp. xi-xiv. By Henrietta Larson. Cambridge: Harvard University Press.

Green, George D. 1972a. Finance and Economic Development in the Old South: Louisiana Banking, 1804-1861. Stanford, Ca.: Stanford University Press.

Green, George D. 1972b. “Louisiana, 1840-1861.” In Banking and Economic Development: Some Lessons from History, pp. 199-231. Edited by Rondo Cameron. New York: Oxford University Press.

Greenwood, Jeremy and Boyan Jovanovic. 1990. "Financial development, growth and the distribution of income." Journal of Political Economy 98(x): 1076-1108.

Greenwwod, Jeremy and Bruce D. Smith. 1997. "Financial markets in development, and the development of financial markets." Journal of Economic Dynamics and Control 210: 145181.

Guiso, Luigi, Paola Sapienza, and Luigi Zingales. 2004a. "Does local financial development matter?" Quarterly Journal of Economics 119(3): 929-969.

Hammond, Bray. 1957. Banks and Politics from the Revolution to the Civil War. Princeton: Princeton University Press.

Heblich, Stephan and Alex Trew. 2014. "Banking and industrialization." Working paper, University of Bristol.

Hoffman, Philip T., Gilles Postel-Vinay, and Jean-Laurent Rosenthal. 2009. Surviving Large Losses: Financial Crises, the Middle Class, and the Development of Capital Markets. Cambridge: Belknap Press of Harvard University Press.

Holt, Michael F. 1999. The Rise and Fall of the American Whig Party: Jacksonian Politics and the Onset of the Civil War. New York: Oxford University Press. 
James, John A. 1976. “The development of the national money market, 1893-1911.” Journal of Economic History 36(4): 878-897.

James, John A. 1995. "The rise and fall of the commercial paper market, 1900-1929." In Anglo-American Financial Systems: Institutions and Markets in the Twentieth Century, pp. 219260. Edited by Michael D. Bordo and Richard Sylla. Burr Ridge, Ill.: Irwin Professional Publishing.

Jaremski, Matthew. 2014. "National banking's role in U.S. industrialization, 1850-1900." Journal of Economic History 74(1): 109-140.

Jaremski, Matthew and Peter L. Rousseau. 2013. "Banks, free banks, and U.S. economic growth.” Economic Inquiry 51(2): 1603-1621.

Keyes, Emerson. 1878. A History of Savings Banks in the United States. New York: Bradford Rhodes.

King, Robert G. and Ross Levine. 1993a. "Finance and growth: Schumpeter might be right." Quarterly Journal of Economics 108(3): 717-737.

King, Robert G. and Ross Levine. 1993b. "Finance, entrepreneurship, and growth: theory and evidence." Journal of Monetary Economics 32(3): 513-542.

Knight, Frank H. 1921. Risk, Uncertainty, and Profit. New York: Hart, Schaffner and Marx.

Kroszner, Randall S., Luc Laeven, and Daniela Klingbiel. 2007. "Banking crises, financial dependence, and growth.” Journal of Financial Economics 84( ): 187-228.

Kroszner, Randall S. and Raghuram G. Rajan. 1994. "Is the Glass-Stegall Act justified? A study of the U.S. experience with universal banking before 1933." American Economic Review 84(4): 810-832.

Kuznets, Simon. 1958. "Foreword." In Financial Intermediaries in the American Economy since 1900, pp. . By Raymond W. Goldsmith. Princeton: Princeton University Press.

Lamoreaux, Naomi R. 1986. "Banks, kinship, and economic development: The New England case." Journal of Economic History 46(3): 647-667.

Lamoreaux, Naomi R. 1994. Insider Lending: Banks, Personal Connections, and Economic Development in Industrial New England. New York: Cambridge University Press.

Lamoreaux, Naomi R. and Christopher Glaisek. 1991. "Vehicles of privilege or mobility? Banks in Providence, Rhode Island during the Age of Jackson.” Business History Review 65(3): 502-527. 
Lamoreaux, Naomi R., Margaret Levenstein, and Kenneth Sokoloff. 2007. "Financing invention during the second industrial revolution: Cleveland, Ohio, 1870-1920." In Financing Innovation in the United States, 1870 to the Present, pp. 39-84. Edited by Naomi R. Lamoreaux and Kenneth Sokoloff. Cambridge, Mass.: MIT Press.

Lamoreaux, Naomi R., Kenneth L. Sokoloff, and Dhanoos Sutthiphisal. 2011. "The reorganization of inventive activity in the United States during the early twentieth century." In Understanding Long-Run Economic Growth: Geography, Institutions, and the Knowledge Economy, pp. 235-275. Edited by Dora L. Costa and Naomi R. Lamoreaux. Chicago: University of Chicago Press.

Larsen, Henrietta M. 1936. Jay Cooke, Private Banker. Cambridge: Harvard University Press.

Levine, Ross. 1997. "Financial development and economic growth: views and agenda." Journal of Economic Literature 35(2): 688-726.

Levine, Ross. 2003. "More on finance and growth: more finance, more growth?” Federal Reserve Bank of St. Louis Review $\mathrm{x}(\mathrm{x})$ : 31-46.

Levine, Ross. 2005. "Finance and growth: theory and evidence." Handbook of Economic Growth. Volume 1A. Edited by Philippe Aghion and Steven N. Durlauf. Elsevier.

Levine, Ross, Chen Lin and Wensi Xie. 2016. "Spare tire? Stock markets, banking crises, and economic recoveries." Journal of Financial Economics 120( ): 81-101.

Lewis, Arthur. 1955. The Theory of Economic Growth. Homewood, Ill.: R. D. Irwin.

Livingood, James W. 1947. The Philadelphia-Baltimore Trade Rivalry, 1780-1860. New York: Arno Press.

McKinnon, Ronald I. 1973. Money and Capital in Economic Development. Washington, D.C.: Brookings Institution.

Miller, M. Sammye. 1980. "An early venture in black capitalism: The Capital Savings Bank in the District of Columbia." Records of the Columbia Historical Society 50: 359-366.

Mokyr, Joel (ed.). 1999. The British Industrial Revolution: An Economic Perspective. Second edition. Boulder, Colorado: Westview Press.

Morck, Randall and Bernard Yeung. 2011. "Economics, history, and causation." Business History Review 85(1): 39-63.

Myers, Margaret G. 1931. The New York Money Market, Origins and Development (2 vols). New York: Columbia University Press. 
National Association of Mutual Savings Banks. 1962. Mutual Savings Banking: Basic Characteristics and Role in the National Economy. Englewood Cliff, N.J.: Prentice-Hall.

Navin, T and M. Sears. 1955. "The rise of a market for industrial securities, 1887-1902." Business History Review 29(1): 105-38.

Neal, Larry. 1971. “Trust companies and financial innovation, 1897-1914.” Business History Review 45(1): 35-51.

Neal, Larry and Eugene N. White. 2012. “The Glass-Steagall Act in historical perspective." Quarterly Review of Economics and Finance 52(1): 104-113.

New York. General Assembly. 1835. “Annual report of the bank commissioners.” Assembly Document No. 74. Albany, NY:

Odell, Kerry A. 1989. "The integration of regional and interregional capital markets: Evidence from the Pacific coast, 1883-1913.” Journal of Economic History 49(2): 297310.

Olmstead, Alan L. 1972. "Investment constraints and New York City mutual savings bank financing of antebellum development." Journal of Economic History 32(4): 811-840.

Olmstead, Alan L. 1974b. "New York City mutual savings bank portfolio management and trustee objectives." Journal of Economic History 34(4): 815-834.

Olmstead, Alan L. 1975. "Mutual savings bank depositors in New York." Business History Review 49(3): 287-311.

Olmstead, Alan L. 1976. New York City Mutual Savings Banks, 1819-1861. Chapel Hill: University of North Carolina Press.

Olstead, Alan L. and Paul W. Rhode. 2008. Creating Abundance: Biological Innovation and American Agricultural Development. New York: Cambridge University Press.

Ott, Julia C. 2011. When Wall Street Met Main Street: The Quest for an Investors' Democracy amd the Emergence of the Retail Investor in the United States, 1890-1930. Cambridge: Harvard University Press.

Pang, Jiaren and Haibin Wu. 2009. "Financial markets, financial dependence, and the allocation of capital." Journal of Banking \& Finance 33( ): 810-818.

Patrick, Hugh T. 1966. "Financial development and economic growth in underdeveloped countries." Economic Development and Cultural Change 14(2): 174-189. 
Payne, Peter Lester and Lance Edwin Davis. 1956. The Savings Bank of Baltimore, 1818-1866: A Historical and Analytical Study. Baltimore: Johns Hopkins University Press.

Phillips, Ronnie J. and Harvery Cutler. 1998. "Domestic exchange rates and regional economic growth in the United States, 1899-1908: Evidence from cointegration analysis." Journal of Economic History 58(4): 1010-1026.

Pollard, Sidney. 1964. "Fixed capital in the industrial revolution in Britain." Journal of Economic History 24(3): 299-314.

Potter, Helen Catherine. 1954. "Savings and Loan Associations and the Consumer Interest."American Journal of Economics and Sociology 13(2): 191-203.

Puri, Manju. 1994. “The long-term default performance of bank underwritten securities issues." Journal of Banking and Finance 18(2): 397-418.

Rajan, Raghuram G. and Luigi Zingales. 2003. Saving Capitalism from the Capitalists: Unleashing the Power of Financial Markets to Create Wealth and Spread Opportunity. New York: Crown Business.

Ramírez, Carlos D. 1999. "Did Glass-Steagall increase the cost of external finance for corporate investment? Evidence from bank and insurance company affiliations." Journal of Economic History 59(2): 372-396.

Ramírez, Carlos D. 2009. 'Bank fragility, 'money under the mattress,' and long-run growth: US evidence from the 'perfect' panic of 1893.” Journal of Banking \& Finance 33(x): 2185-2198.

Ramírez, Carlos D. 2011. "The effect of banking crises on deposit growth: State-level evidence from 1900 to 1930.” Business History 53(2): 270-287.

Ramírez, Carlos D. and J. Bradford DeLong. 1995. "Bank influence and firm performance: The impact of depression-era financial market reforms." In Anglo-American Financial Systems: Institutions and Markets, pp. 161-177. Edited by Michael D. Bordo and Richard Sylla. Burr Ridge, IL: Irwin Publishers.

Ramirez, Carlos D. and Philip A. Shively. 2012. "The effect of bank failures on economic activity: Evidence from U.S. states in the early $20^{\text {th }}$ century." Journal of Money, Credit, and Banking 44(2/3): 433-455.

Redlich, Fritz. 1968. The Molding of American Banking: Men and Ideas. New York: Johnson Reprint Corporation. 
Reinhart, Carmen M. and Kenneth S. Rogoff. 2011. This Time is Different: Eight Centuries of Financial Folly. Princeton: Princeton University Press.

Rhode, Paul W. 2002. Gallman's Annual Output Series for the United States, 1834-1909. National Bureau of Economic Research Working Paper 8860.

Rockoff, Hugh. 1974. "The free banking era: A reexamination." Journal of Money, Credit, and Banking 6(2): 141-167.

Rockoff, Hugh. 1975. "Varieties of banking and regional economic development in the United States, 1840-1860." Journal of Economic History 35(1): 160-181.

Rockoff, Hugh. 1990. “The capital market in the 1850s.” NBER Historical Working Paper \#h11.

Rosen, Deborah. 1992. "Courts and commerce in colonial New York." American Journal of Legal History 36(2): 139-163.

Rostow, Walt Whitman. 196x. The Stages of Economic Growth.

Rothenberg, Winifred B. 1985. "The emergence of a capital market in rural Massachusetts, 1730-1838." Journal of Economic History 45(4): 781-808.

Rottenberg, Dan. 2006. The Man Who Made W all Street: Anthony J. Drexel and the Rise of Modern Finance. Philadelphia: University of Pennsylvania Press.

Rousseau, Peter L. 2003. "Historical perspectives on financial development and economic growth." Federal Reserve Bank of St Louis Review xx: 81-106.

Rousseau, Peter L. and Richard Sylla. 2003. "Financial systems, economic growth, and globalization.” In Globalization in Historical Perspective, pp. 373-416. Edited by Michael D. Bordo, Alan M. Taylor, and Jeffrey G. Williamson. Chicago: University of Chicago Press.

Rousseau, Peter L. and Paul Wachtel. 1998. "Financial intermediation and economic performance: historical evidence from five industrialized countries." Journal of Money, Credit, and Banking 30(4): 657-678.

Rousseau, Peter L. and Richard Sylla. 2005. "Emerging financial markets and early US growth." Explorations in Economic History 42(1): 1-26.

Sabel, Charles F. 1991. "Comment.” In Inside the Business Enterprise: Historical Perspectives on the Use of Information, pp. 236-249. Edited by Peter Temin. Chicago: University of Chicago Press. 
Schumpeter, Joseph A. 1934. The Theory of Economic Development: An Inquiry into Profit, Capital, Credit, Interest, and the Business Cycle. Translated by Redvers Opie. Cambridge: Harvard University Press.

Schweiger, Irving and John S. McGee. 1961. Chicago Banking: The Structure and Performance of Banks and Related Financial Institutions in Chicago and Other Areas. Chicago: University of Chicago Graduate School of Business.

Sellers, Charles. 1991. The Market Revolution: Jacksonian America, 1815-1846. New York: Oxford University Press.

Shaw, Edward S. 1973. Financial Deepening in Economic Development. New York: Oxford University Press.

Shushka, Marie Elizabeth and W. Brian Barrett. 1984. "Banking structure and the national capital market, 1869-1914." Journal of Economic History 44(2): 463-477.

Snowden, Kenneth A. 1987. "Mortgage rates and American capital market development in the late nineteenth century.” Journal of Economic History 47(3): 671-691.

Snowden, Kenneth A. 1988. "Mortgage lending and American urbanization, 1880-1890." Journal of Economic History 48(2): 273-285.

Snowden, Kenneth A. 1995a. "The evolution of interregional mortgage lending channels, 1870-1940: The life insurance-mortgage company connection." In Coordination and Information: Historical Perspectives on the Organization of Enterprise, pp. 209-247. Edited by Naomi R. Lamoreaux and Daniel M. G. Raff. Chicago: University of Chicago Press.

Snowden, Kenneth A. 1995b. "Mortgage securitization in the United States: Twentieth century developments in historical perspective. In Anglo-American Financial Systems: Institutions and Markets in the Twentieth Century, pp. 261-298. Edited by Michael D. Bordo and Richard Sylla. Burr Ridge, Ill.: Irwin Professional Publishing.

Snowden, Kenneth A. 1997. "Building and loan associations in the U.S., 1880-1893: The origins of localization in the residential mortgage market." Research in Economics 51(3): $227-250$.

Sokoloff, Kenneth L. 1984. "Investment in fixed and working capital during early industrialization: Evidence from U.S. manufacturing firms." Journal of Economic History 44(2): 545-556.

Sokoloff, Kenneth L. 1988. "Inventive activity in early industrial America: Evidence from the patent records, 1790-1846." Journal of Economic History 48(4): 813-850. 
Stigler, George. 1967. "Imperfections in the capital market." Journal of Political Economy 75( ): pp.

Sylla, Richard. 1967. "Finance and capital in the United States, 1850-1900." Journal of Economic History 27(4): 621-624.

Sylla, Richard. 1969. "Federal policy, banking market structure, and capital mobilization in the United States, 1863-1913." Journal of Economic History 29(4): 657-686.

Sylla, Richard. 1972. “The United States, 1863-1913.” In Banking and Economic Development: Some Lessons from History, pp. 232-262. Edited by Rondo Cameron. New York: Oxford University Press.

Sylla, Richard. 1975. The American Capital Market, 1846-1914: A Study of the Effects of Public Policy on Economic Development. New York: Arno Press.

Sylla, Richard. 1976. "Forgotten men of money: Private bankers in early American history." Journal of Economic History 36(1): 173-188.

Sylla, Richard. 1998. "U.S. securities markets and the banking system, 1790-1840." Federal Reserve Bank of St. Louis Review 80: 83-104.

Sylla, Richard. 2002. "Financial Systems and Economic Modernization." Journal of Economic History 62(2): 277-292.

Taylor, George Rogers. 1951. The Transportation Revolution, 1815-1860. New York: Holt, Rinehart and Winston.

Teck, Alan. 1968. Mutual Savings Banks and Savings and Loan Associations: Aspects of Growth. New York: Columbia University Press.

Tobin, James. 1958. "Liquidity preference as behavior towards risk." Review of Economic Studies 25(2): 65-86.

Tsuru, Kotaro. 2000. "Finance and growth: some theoretical considerations and a review of the empirical literature.” OECD Economics Department Working Papers No. 228.

Updike, Helen Hill. 1985. The National Banks and American Economic Development, 1870-1900. New York: Garland Publishing, Inc.

Wachtel, Paul and Peter Rousseau. 1995. "Financial intermediation and economic growth: A historical comparison of the United States, United Kingdom, and Canada." In AngloAmerican Financial Systems: Institutions and Markets in the Twentieth Century, pp. 329-382. Edited by Michael D. Bordo and Richard Sylla. Burr Ridge, Ill.: Irwin Professional Publishing. 
Wadhwani, Rohit Daniel. 2002. "Citizen savers: The family economy, financial institutions, and social policy in the northeastern U.S. from the market revolution to the Great Depression.” Ph.D. dissertation: University of Pennsylvania.

Wadhwani, Rohit Daniel. 2004. "Citizen savers: Family economy, financial institutions, and public policy in the nineteenth-century northeast.” Enterprise \& Society 5(4): 617-624.

Wang, Ta-Chen. 2008a. "Banks, credit markets, and early American development: A case study of entry and competition." Journal of Economic History 68(2): 438-461.

Wang, Ta-Chen. 2008b. "Paying back to borrow more: Reputation and bank credit access in early America." Explorations in Economic History 45(4): 477-488.

Wang, Ta-Chen. 2016. "Entry, competition, and terms of credit in early American banking." Research in Economic History, 363-386.

Weiss, Thomas. 1994. "revised conjectures"

Welfling, Weldon. 1939. "Recent savings bank investment policy." Southern Economic Journal 6(1): 33-42.

Welfling, Weldon. 1968. Mutual Savings Banks: The Evolution of a Financial Intermediary. Cleveland, OH: The Press of the Case Western Reserve University.

White, Eugene N. 1982. “The political economy of banking regulation, 1864-1933.” Journal of Economic History 42(): 33-40.

White Eugene N. 1983. The Regulation and Reform of the American Banking System, 1900-1929. Princeton: Princeton University Press.

White, Eugene N. 1986. "Before the Glass-Steagall Act: An analysis of the investment banking activities of national banks." Explorations in Economic History 23(1): 33-55.

White, Eugene N. 1990. “The stock market boom and crash of 1929 revisited." Journal of Economic Perspectives 4(1): 67-84.

Wicker, Elmus. 1995. The Banking Panics of the Great Depression. New York: Cambridge University Press.

Wicker, Elmus. 1999. Banking Panics of the Gilded Age. New York: Cambridge University Press.

Wigmore, Barrie A. 1995. "Some doubts and alternative explanations." In Anglo-American Financial Systems: Institutions and Markets in the Twentieth Century, pp. 207-212. Edited by Michael D. Bordo and Richard Sylla. Burr Ridge, Ill.: Irwin Professional Publishing.

Wright, Robert E. 1999. "Bank ownership and lending patterns in New York and Pennsylvania, 1781-1831.” Business History Review 73(1): 40-60. 
Wright, Robert E. 2011. "Rise of the Corporation Nation." In Founding Choices: American Economic Policy in the 1790s, pp. 217-258. Edited by Douglas A. Irwin and Richard Sylla. Chicago: University of Chicago Press.

Wright, Robert E. 2002. The Wealth of Nations Rediscovered: Integration and Expansion in American Financial Markets, 1780-1850. Cambridge: Cambridge University Press.

Zingales, Luigi. 2003. “Commentary.” Federal Reserve Bank of St. Louis Review x(xx): 47-52.

Zook, George F. 1920. "Thrift in the United States." Annals of the American Academy of Political and Social Science 87: 205-211. 